\title{
Palladium(0)-Alkene Bis(triarylphosphine) Complexes as Catalyst Precursors for the Methoxycarbonylation of Styrene
}

\author{
Jeroen J. M. de Pater, ${ }^{\dagger} \S$ D. S. Tromp, ${ }^{\S}$ Duncan M. Tooke ${ }^{\perp}$ Anthony L. Spek, ${ }^{\perp, \#}$ \\ Berth-Jan Deelman, ${ }^{\ddagger}$ Gerard van Koten, ${ }^{* \dagger}$ and Cornelis J. Elsevier*,§ \\ Debye Institute, Organic Synthesis and Catalysis, and Bijvoet Center for Biomolecular \\ Research, Crystal and Structural Chemistry, Utrecht University, Padualaan 8, \\ NL-3584 CH Utrecht, The Netherlands, Van't Hoff Institute for Molecular Sciences, \\ Molecular Inorganic Chemistry, University of Amsterdam, Nieuwe Achtergracht 166, \\ NL-1018 WV, Amsterdam, The Netherlands, and ARKEMA Vlissingen B.V., P.O. Box 70, \\ NL-4380 AB Vlissingen, The Netherlands
}

Received July 27, 2005

\begin{abstract}
The fluorous complex $\left[\mathrm{Pd}(0)\left(\mathrm{P}\left\{\mathrm{C}_{6} \mathrm{H}_{4}-p-\mathrm{SiMe}_{2}\left(\mathrm{CH}_{2} \mathrm{CH}_{2} \mathrm{C}_{6} \mathrm{~F}_{13}\right)\right\}_{3}\right)_{2}(\mathrm{MA})\right]$ (MA = maleic anhydride) was synthesized and characterized by its NMR spectra. Together with the nonfluorous complexes $\left[\mathrm{Pd}(0)\left(\mathrm{PPh}_{3}\right)_{2}\right.$ (alkene)] (alkene $=\mathrm{C}_{2} \mathrm{H}_{4},(\mathrm{NC})_{2} \mathrm{C}=\mathrm{C}(\mathrm{CN})_{2}, \mathrm{NCC}(\mathrm{H})=$ $\mathrm{C}(\mathrm{H}) \mathrm{CN}$, MA, or benzoquinone) these were evaluated as catalyst precursors in the methoxycarbonylation of styrene. The nonfluorous $\mathrm{C}_{2} \mathrm{H}_{4}$ and $\mathrm{MA}$ complexes gave the highest conversions (the turnover number (TON) was 120; the (average) turnover frequency (TOF) amounted to $80 \mathrm{~h}^{-1}$ ). The fluorous complex gave a significantly lower conversion (TON about 38; TOF $26 \mathrm{~h}^{-1}$ ) than its nonfluorous counterpart, which is caused by a lower stability of the fluorous complex under the reaction conditions.
\end{abstract}

\section{Introduction}

Zerovalent palladium complexes with only alkenes are well-established nowadays as starting materials in modern organometallic chemistry. Examples include homoleptic complexes such as $\left[\mathrm{Pd}_{2}(\mathrm{dba})_{3} \cdot \mathrm{dba}\right]{ }^{1}[\mathrm{Pd}$ $\left.(\mathrm{COD})_{2}\right],{ }^{2}\left[\mathrm{Pd}(\text { ethene })_{3}\right],{ }^{2}$ and $\left[\mathrm{Pd}_{2}(1,6 \text {-diene })_{3}\right]^{3}$ and mixed alkene complexes such as $\left[\operatorname{Pd}(1,6\right.$-diene)(ethene) $],{ }^{3}$ $[\mathrm{Pd}(\text { norbornadiene })(\mathrm{MA})]^{4}(\mathrm{MA}=$ maleic anhydride $)$, and $[\mathrm{Pd}(\mathrm{COD})(\mathrm{MA})] .{ }^{5}$ These complexes, especially $\left[\mathrm{Pd}_{2-}\right.$ $(\mathrm{dba})_{3} \cdot \mathrm{dba}$, serve as important starting materials for the synthesis of zerovalent palladium complexes bearing additional ligands such as phosphines and nitrogen ligands. Their stability is usually governed by a subtle interplay between the electron-donating and electronwithdrawing properties of the ligands and the metal center. Especially diimine ligands, such as the 1,4-diaza-

* Corresponding authors. (G.V.K.) Phone: +31-30-2533120. Fax: +31-30-2523615. E-mail: g.vankoten@chem.uu.nl. (C.J.E.) Phone: +31-20-5255653. Fax: +31-20-5256456. E-mail: else@science.uva.nl. $\dagger$ Debye Institute, Organic Synthesis and Catalysis.

$\S$ Van’t Hoff Institute for Molecular Sciences, Molecular Inorganic Chemistry.

\$ ARKEMA Vlissingen B.V.

${ }^{\perp}$ Bijvoet Center for Biomolecular Research, Crystal and Structural Chemistry.

\# Corresponding author for crystallographic data. Phone: +31-302532538. Fax: +31-30-2523940. E-mail: a.l.spek@chem.uu.nl.

(1) Ukai, T.; Kawazura, H.; Ishii, Y.; Bonnet, J. J.; Ibers., J. A. J. Organomet. Chem. 1974, 65, 253.

(2) (a) Green, M.; Howard, J. A. K.; Spencer, J. L.; Stone, F. G. A. J. Chem. Soc., Chem. Commun. 1975, 449. (b) Green, M.; Howard, J. A. K.; Spencer, J. L.; Stone, F. G. A. J. Chem. Soc., Dalton Trans. 1977, 271.

(3) Krause, J.; Cestaric, G.; Haack, K.-J.; Seevogel, K.; Storm, W.; Pörschke, K.-R. J. Am. Chem. Soc. 1999, 121, 9807.

(4) Itoh, K.; Ueda, F.; Hirai, K.; Ishii, Y. Chem. Lett. 1977, 877880 .

(5) Kluwer, A. M.; Elsevier, C. J.; Bühl, M.; Lutz, M.; Spek, A. L. Angew. Chem., Int. Ed. 2003, 42, 3501. 1,3-butadiene (DAB) and BIAN ligands, have proven to be successful for the synthesis of a variety of palladium(0)-alkene complexes. ${ }^{6-10}$ Recently, Kluwer et al. reported the synthesis of such complexes having monodentate nitrogen ligands. ${ }^{5}$ The complexes with diimine ligands are good catalysts for a number of reactions, such as the selective hydrogenation of alkynes to $Z$ alkenes. ${ }^{8,11}$

Palladium(0)-alkene complexes with phosphines as ligands are also well known. Examples include complexes with monophosphines such as $\left[\mathrm{Pd}\left(\mathrm{PPh}_{3}\right)_{2}\right.$ (alkene)], in which alkene represents MA, tetracyanoethylene (TCNE) ${ }^{7}$ or $\mathrm{C}_{2} \mathrm{H}_{4},{ }^{12}\left[\mathrm{Pd}\left(\mathrm{P}\{n-\mathrm{Bu}\}_{3}\right)_{2}\left(\mathrm{C}_{2} \mathrm{H}_{4}\right)\right],{ }^{13}[\mathrm{Pd}(1-$ $\left.\left(\mathrm{Ph}_{2} \mathrm{P}\right) \mathrm{C}_{6} \mathrm{H}_{4}-2-\mathrm{CH}=\mathrm{NR}\right)($ alkene $\left.)\right],{ }^{14}$ and $\left[\mathrm{Pd}\left(\mathrm{P}\left\{\mathrm{CH}_{2} \mathrm{Ph}\right\}_{3}\right)_{2-}\right.$ $\left.\left(\mathrm{C}_{2} \mathrm{H}_{4}\right)\right]^{15}$ as well as complexes with diphosphines such as $\left[\mathrm{Pd}\right.$ (bis $\{$ diphenylphosphino\}ethane $\left.)\left(\mathrm{C}_{2} \mathrm{H}_{4}\right)\right],{ }^{13}[\mathrm{Pd}$ (bis$\{1,3$-diisopropylphosphino $\}$ propane $\left.)\left(\mathrm{C}_{2} \mathrm{H}_{4}\right)\right],{ }^{16}$ and $[\mathrm{Pd}$ -

(6) Crociani, B.; Di Bianca, F.; Uguagliati, P.; Canovese, L.; Berton, A. J. Chem. Soc., Dalton Trans. 1991, 71 .

(7) Cavell, K. J.; Stufkens, D. J.; Vrieze, K. Inorg. Chim. Acta 1981, 47, 67-76.

(8) van Laren, M. W.; Elsevier, C. J. Angew. Chem., Int. Ed. 1999 38,3715 .

(9) Klein, R. A.; Witte, P.; van Belzen, R.; Fraanje, J.; Goubitz, K.; Numan, M.; Schenk, H.; Ernsting, J. M.; Elsevier, C. J. Eur. J. Inorg. Chem. 1998, 319.

(10) Milani, B.; Anzilutti, A.; Vicentini, L.; Sessanta o Santi, A.; Zangrando, E.; Geremia, S.; Mestroni, G. Organometallics 199716 , 5064 .

(11) Kluwer, A. M.; Koblenz, T. S.; Jorischkeit, T.; Woelk, K.; Elsevier, C. J. J. Am. Chem. Soc. 2005, 127, 15470.

(12) Visser, A.; van der Linde, R.; de Jongh, R. O. Inorg. Synth. 1976, 16,127 .

(13) Paonessa, R. S.; Prignano, A. L.; Trogler, W. C. Organometallics $\mathbf{1 9 8 5}, 4,647$

(14) Scrivanti, A.; Matteoli, U.; Beghetto, V.; Antonaroli, S.; Scarpelli, R.; Crociani, B. J. Mol. Catal. A: Chem. 2001, 170, 51.

(15) Seligson, A. L.; Cowan, R. L.; Trogler, W. C. Inorg. Chem. 1991, 30,3371 . 
Chart 1. Palladium(0)-Alkene Bis(triphenylphosphine) Complexes 1-5 ${ }^{a}$

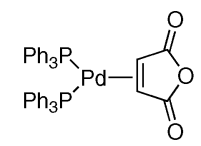

$\left[\mathrm{Pd}(0)\left(\mathrm{PPh}_{3}\right)_{2}(\mathrm{MA})\right](\mathbf{1})$
$\left[\mathrm{Pd}(0)\left(\mathrm{PPh}_{3}\right)_{2}(\mathrm{TCNE})\right](\mathbf{2})$

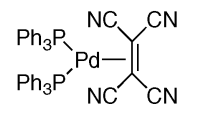

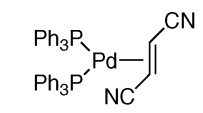

$\left[\mathrm{Pd}(0)\left(\mathrm{PPh}_{3}\right)_{2}(\mathrm{FN})\right](3)$

$$
\mathrm{Ph}_{3} \mathrm{P}^{\prime} \mathrm{Pd}
$$

$\left[\mathrm{Pd}(0)\left(\mathrm{PPh}_{3}\right)_{2}(\mathrm{BQ})\right](4)$

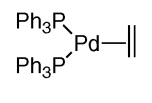

$\left[\mathrm{Pd}(0)\left(\mathrm{PPh}_{3}\right)_{2}\left(\mathrm{C}_{2} \mathrm{H}_{4}\right)\right](5)$
${ }^{a}$ Legend: $\mathrm{MA}=$ maleic anhydride; $\mathrm{TCNE}=$ tetracyanoethylene; $\mathrm{FN}=$ fumaronitrile; $\mathrm{BQ}=$ benzoquinone.

(4,5-bis $\{$ (diphenylphosphino)methyl $\}$-2,2-dimethyl-1,3dioxolane $\left.)\left(\mathrm{C}_{2} \mathrm{H}_{4}\right)\right] .{ }^{17}$ They have been proposed as intermediates in several catalytic reactions and are sometimes used as catalyst precursors. Well-known examples of the latter use are the compounds $[\mathrm{Pd}(0)(\mathrm{P}-\mathrm{N})$ (alkene)] (alkene $=$ fumaronitrile or dimethyl fumarate, $\mathrm{P}-\mathrm{N}=1-\left(\mathrm{Ph}_{2} \mathrm{P}\right) \mathrm{C}_{6} \mathrm{H}_{4}-2-\mathrm{CH}=\mathrm{NR}\left(\mathrm{R}=\mathrm{CMe}_{3}\right.$ or $\mathrm{C}_{6} \mathrm{H}_{4}-$ OMe-4)), which have been used as precursor complexes in the methoxycarbonylation of alkynes. ${ }^{14}$

We have recently investigated the use of $\left[\mathrm{Pd}(\mathrm{OAc})_{2^{-}}\right.$ $\left.\left(\mathrm{PAr}_{3}\right)_{2}\right]$ complexes as precursors in the methoxycarbonylation of styrene. ${ }^{18}$ In these studies one of the complexes used was the so-called fluorous complex [Pd$\left.(\mathrm{OAc})_{2}\left(\mathrm{P}\left\{\mathrm{C}_{6} \mathrm{H}_{4}-p-\mathrm{SiMe}_{2}\left(\mathrm{CH}_{2} \mathrm{CH}_{2} \mathrm{C}_{6} \mathrm{~F}_{13}\right)\right\}_{3}\right)_{2}\right]$. One of the problems with the fluorous complex is its low activity and long induction period. We were therefore interested in the development of other palladium phosphine complexes that could give a more direct entry into the catalytic cycle of the methoxycarbonylation process. A viable option, we reasoned, would be the use of palladium(0)-alkene complexes. Here we report on the synthesis of a number of palladium(0)-alkene complexes with nonfluorous monodentate phosphines and one complex with fluorous monodentate phosphines and their application as catalyst precursors in the methoxycarbonylation of styrene.

\section{Results}

Synthesis of Palladium(0)-Alkene Complexes. A number of palladium(0) complexes with different alkenes were synthesized (Chart 1). Known complexes $\mathbf{1}$, $\mathbf{2},{ }^{7} \mathbf{4},{ }^{19}$ and $\mathbf{5}^{12}$ were synthesized according to published methods in good yields and purity. Known complexes 3 and 6 were prepared using the method depicted in eqs 1 and 2 (Scheme 1), ${ }^{7}$ which led to increased yields in comparison with the literature method. ${ }^{6}$ Crystals suitable for single-crystal X-ray structure determination were obtained from a concentrated solution of complex 6 in acetone. Its structure is given in Figure 1, and the relevant bond lengths and angles are compiled in Table 1.

(16) Perez, P. J.; Calabrese, J. C.; Bunel, E. E. Organometallics 2001, $20,337$.

(17) Hodgson, M.; Parker, D.; Taylor, R. J.; Ferguson, G. Organometallics 1988, 7, 1761.

(18) de Pater, J. J. M.; Elsevier, C. J.; Deelman, B.-J.; van Koten, G. Submitted for publication.

(19) Minematsu, H.; Takahashi, S.; Hagihara, N. J. Organomet. Chem. 1975, 91, 389-398.
The complex shows the Y-shaped trigonal-planar geometry that has also been previously observed for related complexes such as [palladium $(0)\left(N, N^{\prime}\right.$-diphenyl1,7,7-trimethylbicyclo[2.2.1] heptane-2,3-diimine- $\left.N, N^{\prime}\right)$ (fumaronitrile) ${ }^{20}$ and [palladium(II)(Me) $)_{2}(2$-(phenylimino)-3-(2,6-dimethylphenylimino)-1,7,7-trimethylbicyclo-[2.2.1]heptane-2,3-diylidene)]. ${ }^{21}$ The $\mathrm{Pd}-\mathrm{N}$ (2.153(5) $\AA$ ) and $\mathrm{Pd}-\mathrm{C}$ distances $(2.045(5) \AA)$ are also in agreement with previously reported values. ${ }^{20}$ The N(1)$\mathrm{Pd}(1)-\mathrm{N}(1)$ a bite angle of $76.32(12)^{\circ}$ is somewhat smaller than values known in the literature for related complexes (values of $77.2-77.5^{\circ}$ are reported ${ }^{20-22}$ ). As expected, upon coordination of the alkene, an elongation of the $\mathrm{C}=\mathrm{C}$ bond distance $(1.417(6) \AA$ ) when compared with the free ligand $(1.249(10) \AA)^{23}$ and a concomitant expected shortening of the $\mathrm{C}-\mathrm{CN}$ bonds (1.435(7) $\AA$ ) when compared with the free ligand (1.480(8) $\AA$ ) are observed. ${ }^{23}$ Judging from the $\mathrm{C}-\mathrm{C}-\mathrm{C}$ angles in the alkene ligand $\left(119.1(5)^{\circ}\right)$, the olefinic carbon atoms are $\mathrm{sp}^{2}$ hybridized.

NMR Studies on Palladium-Alkene Complexes 1, 3, and 5. Complexes 1 and $\mathbf{3}$ have been characterized previously by ${ }^{1} \mathrm{H}$ NMR spectroscopy and elemental analysis, whereas $\mathbf{5}$ has been characterized only by elemental analysis. In the present study we also recorded their ${ }^{13} \mathrm{C}\left\{{ }^{1} \mathrm{H}\right\}$ and ${ }^{31} \mathrm{P}\left\{{ }^{1} \mathrm{H}\right\} \mathrm{NMR}$ spectra (for full data see Experimental Section) and for 5 also its ${ }^{1} \mathrm{H}$ NMR spectrum. For complexes $\mathbf{1}$ and $\mathbf{3}$ the region of the spectra where the alkene ${ }^{13} \mathrm{C}$ resonances were observed is given in Figure 2 (3 on the left side, $\mathbf{1}$ on the right).

It is obvious from Figure 2 that the alkene carbon region for $\mathbf{1}$ and $\mathbf{3}$ shows somewhat different patterns. For both $\mathbf{1}$ and $\mathbf{3}$ the observed patterns are the X-part of an $\mathrm{AA}^{\prime} \mathrm{X}$ system. For 3 simulation of these signals (Figure 2, bottom left, using the WINDNMR program ${ }^{24}$ ) showed that the observed multiplet structure corresponds to the $\mathrm{X}$ part of an $\mathrm{AA}^{\prime} \mathrm{X}$ pattern $\left(\mathrm{A}={ }^{31} \mathrm{P}\right.$ nucleus, $\mathrm{A}^{\prime}={ }^{31} \mathrm{P}$ nucleus) with no exchange processes involved. ${ }^{25}$ When the ${ }^{13} \mathrm{C}\left\{{ }^{1} \mathrm{H}\right\}$ NMR spectrum was recorded while applying simultaneous ${ }^{1} \mathrm{H}$ - and ${ }^{31} \mathrm{P}$ decoupling, this multiplet pattern for the alkene carbon atoms collapsed to a singlet. This confirms that coupling of these alkene carbon atoms to phosphorus atoms, which are at the cis- and trans-position, respectively, causes the observed pattern. For complex 1 (with MA as the alkene), a different pattern was observed for the alkene carbon atoms in its ${ }^{13} \mathrm{C}\left\{{ }^{1} \mathrm{H}\right\} \mathrm{NMR}$ spectrum (Figure 2, top right). Simulation of this pattern (Figure 2 , bottom right) showed that it is also the $\mathrm{X}$ part of an AA'X pattern, but now with exchange present between the $\mathrm{A}$ and $\mathrm{A}^{\prime}$ sites. ${ }^{26}$ Also for this compound application

(20) Ellis D. D.; Spek, A. L. Acta Crystallogr. C 2001, 57, 235.

(21) Schleis, T.; Heinemann, J.; Spaniol, T. P.; Mulhaupt, R.; Okuda J. Inorg. Chem. Commun. 1998, 1, 431.

(22) Ferrara, M. L.; Giordana, F.; Orabona, I.; Panunzi, A.; Ruffo, F. Eur. J. Inorg. Chem. 1999, 1939.

(23) Britton, D.; Gleason, W. B. Cryst. Struct. Commun. 1982, 11, 1155 .

(24) Reich, H. J. WINDNMR: NMR Spectrum Calculations, version 7.1.6; Department of Chemistry, University of Wisconsin: Madison, WI, 2002 .

(25) The following values were used in the simulation of the alkene region of 3: $J_{\mathrm{AA}^{\prime}}=6.0 \mathrm{~Hz}, J_{\mathrm{AX}}=-5.9 \mathrm{~Hz}$ (cis-phosphine), $J_{\mathrm{AX}^{\prime}}=36.5$ $\mathrm{Hz}$ (trans-phosphine), $K_{\mathrm{AA}^{\prime}}=0$.

(26) For 1 the following values were used in the simulation of the alkene region: $J_{\mathrm{AA}^{\prime}}=11.0 \mathrm{~Hz}, J_{\mathrm{AX}}=-6.1 \mathrm{~Hz}$ (cis-phosphine), $J_{\mathrm{A}^{\prime} \mathrm{X}}=$ $28.7 \mathrm{~Hz}$ (trans-phosphine), $K_{\mathrm{AA}^{\prime}}=4$. 
Scheme 1. Synthetic Route for Complex $3^{a}$

$\left[\mathrm{Pd}_{2}(\mathrm{dba})_{3} \cdot \mathrm{dba}\right] \frac{\begin{array}{c}1.1 \text { equiv. } \mathrm{NCC}(\mathrm{H})=\mathrm{C}(\mathrm{H}) \mathrm{CN} \\ \begin{array}{c}1.1 \text { equiv. } t-\mathrm{BuDAB} \\ \text { acetone, RT }\end{array}\end{array}[\mathrm{Pd}(0)(t-\mathrm{BuDAB})(\mathrm{NCC}(\mathrm{H})=\mathrm{C}(\mathrm{H}) \mathrm{CN})]}{6}$

$[\mathrm{Pd}(0)(t-\mathrm{BuDAB})(\mathrm{NCC}(\mathrm{H})=\mathrm{C}(\mathrm{H}) \mathrm{CN})] \frac{2.15 \text { equiv. } \mathrm{PPh}_{3}}{\text { acetone, } \mathrm{RT}}\left[\mathrm{Pd}(0)\left(\mathrm{PPh}_{3}\right)_{2}(\mathrm{NCC}(\mathrm{H})=\mathrm{C}(\mathrm{H}) \mathrm{CN})\right]$

3

${ }^{a}$ Legend: $\mathrm{dba}=(1 E, 4 E)$-1,5-diphenylpenta-1,4-dien-3-one; $t$-BuDAB $=3,6$-diaza-2,2,7,7-tetramethyl-octa-3,5-diene.

Table 1. Selected Bond Lengths, Bond Angles, and Torsion Angles for $6^{a}$

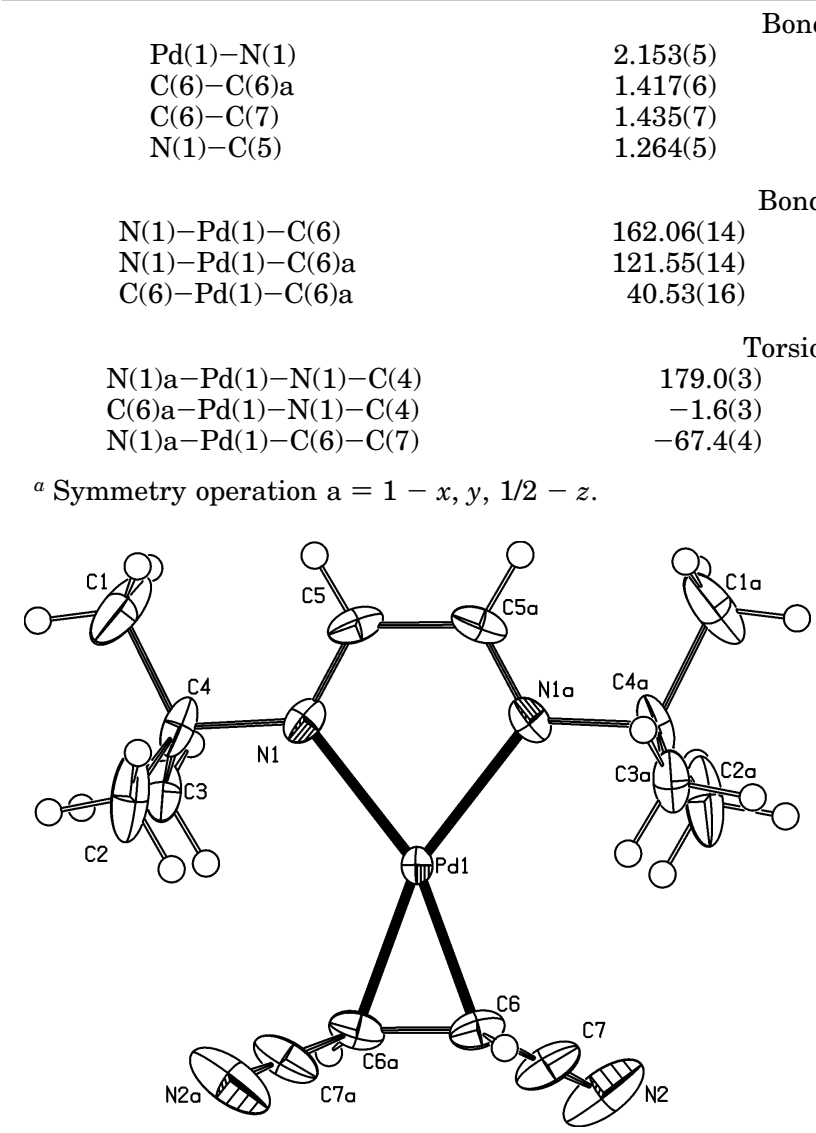

Figure 1. ORTEP plot of 6. Displacement ellipsoids are drawn at the $50 \%$ probability level. Symmetry operation $a$ $=1-x, y, 1 / 2-z$.

of both ${ }^{1} \mathrm{H}$ - and ${ }^{31} \mathrm{P}$-decoupling resulted in a collapse of the multiplet signal into a singlet, again showing that the splitting is caused by coupling to phosphorus atoms in cis- and trans-positions, respectively. The appearance of such AA'X patterns has been reported previously for related platinum complexes such as $\left[\mathrm{Pt}(0)\left(\mathrm{PPh}_{3}\right)_{2}\right.$ (trans $\left.\left.\left\{\mathrm{CH}\left(\mathrm{CO}_{2} \mathrm{Et}\right)=\mathrm{C}\left(\mathrm{CO}_{2} \mathrm{Et}\right) \mathrm{H}\right\}\right)\right]^{27}$ and $\left[\mathrm{Pt}(0)\left(\mathrm{PPh}_{3}\right)_{2}\left(\mathrm{H}_{2} \mathrm{C}=\right.\right.$ $\mathrm{C}(\mathrm{CN}) \mathrm{H}){ }^{28}$ For both $\mathbf{1}$ and $\mathbf{3}$ the signals for the ipso-, ortho-, and meta-C atoms of $\mathrm{PPh}_{3}$ were observed as virtual triplets due to virtual coupling. ${ }^{29-31}$

The instability of complex $\mathbf{5}$ in solution in the absence of additional ethene hampered NMR studies on this

(27) Guedes da Silva, M. F. C.; Fraústo, J. J. R.; Pombeiro, A. J. L.; Bertani, R.; Michelin, R. A.; Mozzon, M.; Benetollo, F.; Bombieri, G. Inorg. Chim. Acta 1993, 214, 85

(28) Asaro, F.; Lenarda, M.; Pellizer, G.; Storaro, L. Spectrochim. Acta Part A 2000, 56, 2167.

(29) The appearance of these triplets is due to virtual ${ }^{31} \mathrm{P}$-coupling. Such a resonance pattern is observed for AA'X spins systems when $J_{\mathrm{AA}^{\prime}} \gg\left(v_{\mathrm{A}}-v_{\mathrm{A}^{\prime}}\right)+\left(J_{\mathrm{AX}}+J_{\mathrm{AX}}\right) / 2$, see: Wiberg, K. B., Nist, B. J., Eds Interpretation of NMR Spectra; W. A. Benjamin, Inc.: New York, 1962; pp 21-27. The appearance of such virtual triplets is not uncommon for $\mathrm{PPh}_{3}$ ligands when coordinated to metal centers. It has for instance been observed for the complex $\left[\mathrm{Pt}\left(\mathrm{PPh}_{3}\right)_{2}\right.$ (trans $-\mathrm{CH}\left(\mathrm{CO}_{2} \mathrm{Et}\right)=\mathrm{CH}\left(\mathrm{CO}_{2}\right.$ Et))]; see ref 27. complex. Therefore, the NMR solvents used (toluene$d_{8}$ and $\mathrm{CD}_{2} \mathrm{Cl}_{2}$ ) were first saturated with ethene before they were added to the complex. The ${ }^{1} \mathrm{H}$ NMR spectrum of this complex, when measured at ambient temperature, showed a broad signal due to exchange of free ethene molecules present in solution with those that are coordinated to the palladium complex. This exchange process probably proceeds via an associative exchange mechanism. When toluene- $d_{8}$ was used as solvent, assignment of the signals in the ${ }^{13} \mathrm{C}\left\{{ }^{1} \mathrm{H}\right\}$ NMR was hampered by overlap of the signals from the carbon atoms of $\mathrm{PPh}_{3}$ and those of toluene. This overlap was not resolved by cooling of the sample to $-40{ }^{\circ} \mathrm{C}$. Lower temperatures were not possible, because of the viscosity of the solution, leading to very broad signals. Surprisingly, the ${ }^{13} \mathrm{C}$ signals for the $\mathrm{CH}_{2}$ groups of ethene were not observed in the ${ }^{13} \mathrm{C}\left\{{ }^{1} \mathrm{H}\right\}$ NMR spectrum in this solvent, neither at ambient temperature nor at lower temperature down to $-40{ }^{\circ} \mathrm{C}$. In its ${ }^{1} \mathrm{H}$ NMR spectrum at $-40{ }^{\circ} \mathrm{C}$, two broad singlets were observed for the $\mathrm{CH}_{2}$ groups of ethene: one at $4.00 \mathrm{ppm}$ and one at $5.30 \mathrm{ppm}$. The former corresponds to coordinated ethene, while the latter corresponds to free ethene in solution. In the ${ }^{31} \mathrm{P}$ $\left\{{ }^{1} \mathrm{H}\right\}$ NMR spectra a singlet $(\delta=27.47 \mathrm{ppm})$ was observed over the entire temperature range studied.

In $\mathrm{CD}_{2} \mathrm{Cl}_{2}$, complex 5 was less stable than in toluene$d_{8}$, especially at ambient temperature. At low temperature $\left(-60{ }^{\circ} \mathrm{C}\right)$ again the ${ }^{1} \mathrm{H}$ NMR spectrum showed two signals corresponding to free and coordinated ethene, respectively. These signals were still broad though, indicating that intermolecular exchange is still taking place at this temperature. In the aromatic region of the ${ }^{13} \mathrm{C}\left\{{ }^{1} \mathrm{H}\right\}$ NMR spectrum at $-60{ }^{\circ} \mathrm{C}$ the signals corresponding to the ipso-C and ortho- $\mathrm{C}$ of the $\mathrm{PPh}_{3}$ were observed as the expected virtual triplets, ${ }^{29}$ whereas the other two signals (meta-C and para-C of $\mathrm{PPh}_{3}$ ) were still

(30) For a more extensive review on the appearance of several splitting patterns observed in $\left[\mathrm{M}\left(\mathrm{PR}_{3}\right)_{2} \mathrm{X}_{2}\right]$ complexes, see: Verkade, J. G. Coord. Chem. Rev. 1972/1973, 9, 1 .

(31) With ${ }^{31}$ P-decoupling applied, also all the triplets observed in the aromatic region collapsed to singlets, proving that the observed patterns are due to coupling with ${ }^{31} \mathrm{P}$ nuclei. 

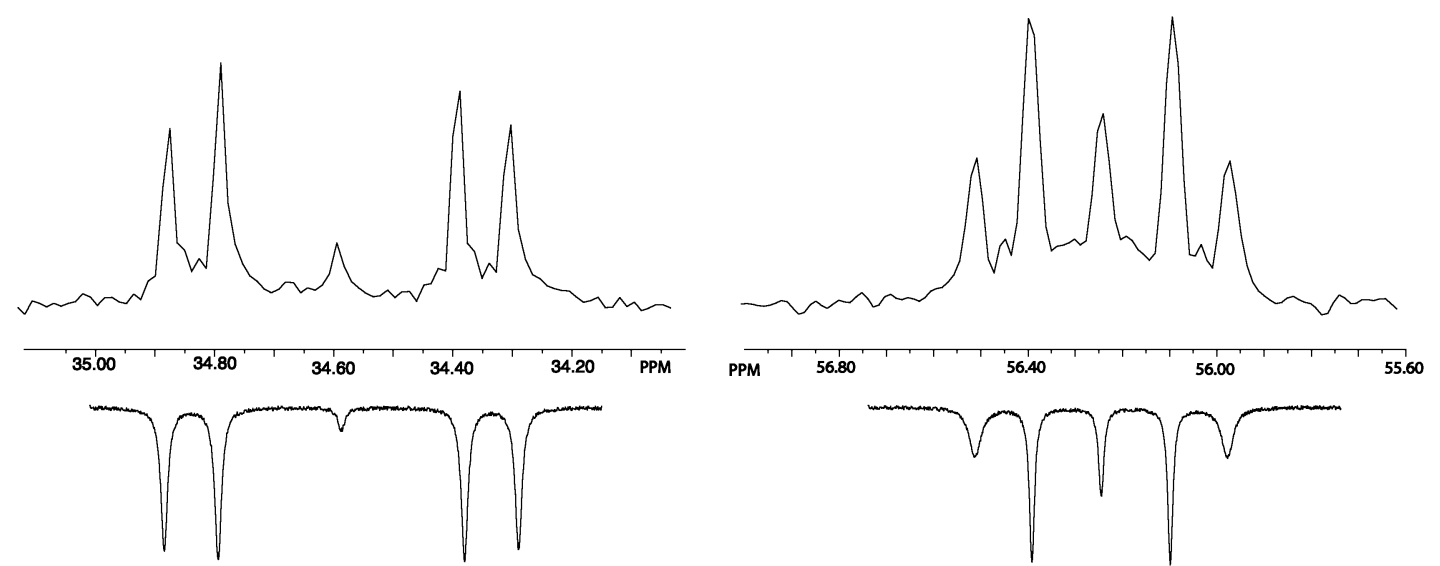

Figure 2. ${ }^{13} \mathrm{C}\left\{{ }^{1} \mathrm{H}\right\} \mathrm{NMR}(75.5 \mathrm{MHz})$ spectra, alkene region, for $\mathbf{3}$ (left) and $\mathbf{1}$ (right). Observed spectra at the top, calculated spectra at the bottom.

\author{
Scheme 2. Synthesis of Complex 7, Starting from [Pd(0)(t-Bu-DAB)(MA)] \\ $[\mathrm{Pd}(0)(t-\mathrm{Bu}-\mathrm{DAB})(\mathrm{MA})] \frac{2 \mathrm{P}\left\{\mathrm{C}_{6} \mathrm{H}_{4}-p-\mathrm{SiMe}_{2}\left(\mathrm{CH}_{2} \mathrm{CH}_{2} \mathrm{C}_{6} \mathrm{~F}_{13}\right)\right\}_{3}}{\text { acetone, } \mathrm{RT}}\left[\mathrm{Pd}(\mathrm{O})\left(\mathrm{P}\left\{\mathrm{C}_{6} \mathrm{H}_{4}-p-\mathrm{SiMe}_{2}\left(\mathrm{CH}_{2} \mathrm{CH}_{2} \mathrm{C}_{6} \mathrm{~F}_{13}\right)\right\}_{3}\right)_{2}(\mathrm{MA})\right]$
}

Scheme 3. Synthetic Route for Complex 7, Starting from [Pd(0)(MA)(norbornadiene)]

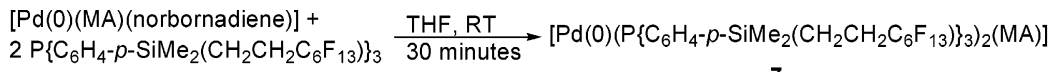

observed as singlets. The signals for ethene, either for free or coordinated ethene, were not observed even at this low temperature in the ${ }^{13} \mathrm{C}\left\{{ }^{1} \mathrm{H}\right\} \mathrm{NMR}$ spectrum. Decreasing the temperature beyond $-60{ }^{\circ} \mathrm{C}$ was not possible, because the complex precipitated from the solution upon further cooling. Its ${ }^{31} \mathrm{P}\left\{{ }^{1} \mathrm{H}\right\}$ NMR spectrum showed in the whole temperature range two signals: a large broad singlet at $26.95 \mathrm{ppm}$ (which sharpened at low temperatures), ascribed to complex $\mathbf{5},{ }^{32}$ and a minor singlet at $33.85 \mathrm{ppm}$. The latter signal could correspond to a zerovalent palladium complex with three (or four) phosphines, formed from the reaction of complex 5 with free $\mathrm{PPh}_{3}$, which is present because complex $\mathbf{5}$ had partly decomposed.

Synthesis of Fluorous Pd(0)-Alkene Complexes. After having tested the complexes $\mathbf{1 - 5}$ in the methoxycarbonylation of styrene (vide infra) we decided to synthesize only the fluorous versions of the most active complexes, i.e., the complexes with MA and ethene as the alkene. The synthesis of $\left[\mathrm{Pd}(0)\left(\mathrm{P}\left\{\mathrm{C}_{6} \mathrm{H}_{4}-p-\mathrm{SiMe}_{2}\left(\mathrm{CH}_{2}-\right.\right.\right.\right.$ $\left.\left.\left.\left.\mathrm{CH}_{2} \mathrm{C}_{6} \mathrm{~F}_{13}\right)\right\}_{3}\right)_{2}(\mathrm{MA})\right]$ (7) was first attempted using the same route as has been used for complex 1 (Scheme 2).

Although formation of the desired complex was observed, as was evident from ${ }^{31} \mathrm{P}\left\{{ }^{1} \mathrm{H}\right\}$ and ${ }^{1} \mathrm{H}$ NMR spectra of the crude product after the same workup as for $\mathbf{1}$, its ${ }^{1} \mathrm{H}$ NMR spectrum also showed the presence of free $t$-BuDAB. Because of similar solubilities of $t$-BuDAB and palladium complex 7 in the washing solvent $\left(\mathrm{Et}_{2} \mathrm{O}\right)$, its removal was not possible. Several other methods, i.e., extraction with methanol and $n$ pentane at both ambient and low temperatures as well as removal of the $t$-BuDAB by sublimation, were tried. The first method gave some improvement in purity after several extractions (ca. $10 \%$ free $t$-BuDAB was left). However, because of the appreciable solubility of 7 in these solvents, even at low temperatures, a very low

(32) In toluene- $d_{8}$ the ${ }^{31} \mathrm{P}$ NMR spectrum of 5 showed one singlet at $27.47 \mathrm{ppm}$. yield of the complex resulted. The second method cleanly removed the free $t$-BuDAB from the complex, but at the same time induced appreciable decomposition of the palladium complex, resulting in a low yield of the desired complex.

Because of these problems, the route recently developed by Kluwer et al., ${ }^{5}$ which allowed for the synthesis of zerovalent palladium alkene complexes with monodentate nitrogen ligands, was used to obtain pure 7 in higher yields (eq 4, Scheme 3). Using this method, very pure 7 was obtained in an acceptable yield indeed. Its ${ }^{1} \mathrm{H},{ }^{13} \mathrm{C}\left\{{ }^{1} \mathrm{H}\right\}$, and ${ }^{31} \mathrm{P}\left\{{ }^{1} \mathrm{H}\right\} \mathrm{NMR}$ spectra showed the expected signals for this compound, as well as those for the perfluoroalkyl chain in its ${ }^{13} \mathrm{C}\left\{{ }^{1} \mathrm{H}\right\}$ and ${ }^{19} \mathrm{~F}$ NMR spectra. Furthermore, because of the presence of the fluorous phosphines in complex 7, it also shows appreciably solubility (more than $20 \mathrm{mg} / \mathrm{mL}$ ) in apolar solvents such as $n$-hexane and $\mathrm{Et}_{2} \mathrm{O}$.

The synthesis of $\left[\mathrm{Pd}(0)\left(\mathrm{P}\left\{\mathrm{C}_{6} \mathrm{H}_{4}-p-\mathrm{SiMe}_{2}\left(\mathrm{CH}_{2} \mathrm{CH}_{2^{-}}\right.\right.\right.\right.$ $\left.\left.\left.\left.\mathrm{C}_{6} \mathrm{~F}_{13}\right)\right\}_{3}\right)_{2}\left(\mathrm{C}_{2} \mathrm{H}_{4}\right)\right]$ (8) was attempted following the same synthetic procedure as that for 5.12 Although the complex seemed to form, as judged by color changes of the reaction mixture, isolation of the compound appeared to be impossible. Precipitation by addition of $\mathrm{Et}_{2} \mathrm{O}$ to the reaction mixture did not work, and neither did the use of several other solvents. Rapid formation of palladium black was observed once ethene was removed. Further efforts to prepare this compound were therefore abandoned.

Catalysis. The compounds $\mathbf{1} \mathbf{- 5}$ were tested as precursors in the catalytic methoxycarbonylation of styrene (Scheme 4). To allow for comparison with our data on the use of $\left[\mathrm{Pd}(\mathrm{OAc})_{2}\left(\mathrm{PPh}_{3}\right)_{2}\right]$ as the catalyst precursor, ${ }^{18}$ the same reaction conditions (such as palladium concentration, $\mathrm{Pd}$ :styrene, $\mathrm{Pd}$ :acid, and $\mathrm{Pd}: \mathrm{H}_{2} \mathrm{O}$ ratios) were applied in the present study with the palladium $(0)$ precursors. The data for $\mathbf{1}-\mathbf{5}$ and $\left[\mathrm{Pd}(\mathrm{OAc})_{2}\left(\mathrm{PPh}_{3}\right)_{2}\right]$ are presented in Table 2. 
Scheme 4. General Reaction Scheme for Methoxycarbonylation of Styrene
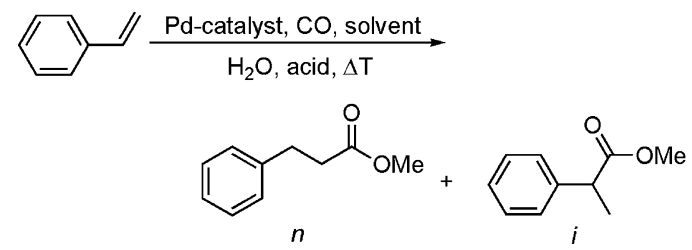

Table 2. Results for Methoxycarbonylation of Styrene with $1-5$ and $\left[\mathrm{Pd}(\mathrm{OAc})_{2}\left(\mathrm{PPh}_{3}\right)_{2}\right]^{a}$

\begin{tabular}{|c|c|c|c|}
\hline entry & complex & conversion $(\%)$ & $i: n$ \\
\hline 1 & 1 & 80 & $41: 59$ \\
\hline 2 & 2 & 2 & $42: 58$ \\
\hline 3 & 3 & 40 & $40: 60$ \\
\hline 4 & 4 & 27 & $41: 59$ \\
\hline 5 & 5 & 80 & 41:59 \\
\hline 6 & {$\left[\mathrm{Pd}(\mathrm{OAc})_{2}\left(\mathrm{PPh}_{3}\right)_{2}\right]^{b}$} & $>95$ & $40: 60$ \\
\hline
\end{tabular}

${ }^{a}$ General conditions: $[\mathrm{Pd}]=2 \mu \mathrm{mol} / \mathrm{mL}, \mathrm{Pd}$ :styrene: $\mathrm{HO}_{3} \mathrm{SC}_{6} \mathrm{H}_{4-}$ $p$-Me $(p$-tsaH $): \mathrm{H}_{2} \mathrm{O}=1: 150: 30: 600$, solvent $=\mathrm{MeOH} / \alpha, \alpha^{\prime}, \alpha^{\prime \prime}-$ trifluorotoluene, $1: 1(\mathrm{v} / \mathrm{v})$, reaction time $=90 \mathrm{~min}, T=80^{\circ} \mathrm{C}, 30$ bar CO. ${ }^{b}$ Data taken from ref 18.

\section{Scheme 5. Formation of a Palladium(II)-Hydride Species from a Palladium(0) Alkene Complex}

$\left[\mathrm{Pd}(0)\left(\mathrm{PPh}_{3}\right)_{2}\right.$ (alkene)] $\underset{\text { oxidative addition }}{1 \text { equiv. } \mathrm{HO}_{3} \mathrm{SC}_{6} \mathrm{H}_{4}-\mathrm{p}-\mathrm{Me}}$

$$
\left[\mathrm{Pd}(\mathrm{H})\left(\mathrm{O}_{3} \mathrm{SC}_{6} \mathrm{H}_{4}-p-\mathrm{Me}\right)\left(\mathrm{PPh}_{3}\right)_{2}\right]
$$

Several observations can be made. The first one is that the conversion after $90 \mathrm{~min}$ is dependent on the nature of the alkene in the precursor and increases in the order $\mathrm{TCNE}<\mathrm{BQ}<\mathrm{FN}<\mathrm{MA}, \mathrm{C}_{2} \mathrm{H}_{4}<\left[\mathrm{Pd}(\mathrm{OAc})_{2}-\right.$ $\left.\left(\mathrm{PPh}_{3}\right)_{2}\right]$. With $\left[\mathrm{Pd}(\mathrm{OAc})_{2}\left(\mathrm{PPh}_{3}\right)_{2}\right]$ as precursor the highest conversion is obtained, while the results with either complex $\mathbf{1}$ or $\mathbf{5}$ as precursor compare quite favorably with the results obtained with the palladium(II) precursor. Apparently the $i: n$ ratio is the same (within experimental error) for every complex used and independent of the nature of palladium starting precursor. This provides evidence that probably in all cases the same catalytic species is generated and present as the active species in solution. Although conclusive evidence is not available yet, a viable species that could be the starting point for catalysis is the palladium(II) hydride compound $\left[\mathrm{Pd}(\mathrm{H})\left(\mathrm{O}_{3} \mathrm{SC}_{6} \mathrm{H}_{4}-p-\mathrm{Me}\right)\left(\mathrm{PPh}_{3}\right)_{2}\right]$. Such a species has been proposed by others to be the actual precatalyst for this reaction ${ }^{33}$ and is formed from the palladium(0) complexes via the reaction of the added acid with the palladium(0) complex (Scheme 5). ${ }^{34-36}$

It is interesting to note that differences in color between the different catalyst precursors were observed

(33) Seayad, A.; Jayasree, S.; Damodaran, K.; Toniolo, L.; Chaudahri, R. V. J. Organomet. Chem. 2000, 601, 100.

(34) The formation of hydrido-palladium complexes from the reaction of palladium( 0 ) complexes with an acid can be regarded either as the protonation of the basic palladium $(0)$ (when strong acids are used such as $\mathrm{HBF}_{4}$ and $\mathrm{HO}_{3} \mathrm{SC}_{6} \mathrm{H}_{4}-p-\mathrm{Me}$ ) or as an oxidative addition (when weak acids are used). In the former reaction the formed palladium complex can be considered as either $\mathrm{Pd}(0)$ ligated by a proton or $\mathrm{Pd}(\mathrm{II})$ ligated by a hydride. Since the Pd- $H$ signal is observed at very negative ppm values, indicative of a palladium-hydride, this first reaction is therefore usually also considered as an oxidative addition reaction. See: Amatore, C.; Jutand, A.; Meyer, G.; Carelli, I.; Chiarotto, I. Eur. J. Inorg. Chem. 2000, 1855, and references therein.

(35) Oxidative addition of acids to palladium(0) alkene complexes has been reported earlier in the literature, see refs 15 and 17.

(36) For a review on several methods of synthesizing palladiumhydride complexes as well as their reactions, see: Grushin, V. V. Chem. Rev. 1996, 96, 2011, and references therein.
Table 3. Results for Methoxycarbonylation of Styrene with 1,5 , and $\left[\mathrm{Pd}(\mathrm{OAc})_{2}\left(\mathrm{PPh}_{3}\right)_{2}\right]$ at $60^{\circ} \mathrm{C}^{a}$

\begin{tabular}{clcc}
\hline entry & \multicolumn{1}{c}{ complex } & conversion $(\%)$ & $i: n$ \\
\hline 1 & $\mathbf{1}$ & 54 & $62: 38$ \\
2 & $\mathbf{5}$ & 63 & $63: 37$ \\
3 & {$\left[\mathrm{Pd}(\mathrm{OAc})_{2}\left(\mathrm{PPh}_{3}\right)_{2}\right]^{b}$} & 45 & $65: 35$
\end{tabular}

${ }^{a}$ General conditions: $[\mathrm{Pd}]=2 \mu \mathrm{mol} / \mathrm{mL}, \mathrm{Pd}$ :styrene: $\mathrm{HO}_{3} \mathrm{SC}_{6} \mathrm{H}_{4}$ $p$-Me $\left(p\right.$-tsaH): $\mathrm{H}_{2} \mathrm{O}=1: 150: 30: 600$, solvent $=\mathrm{MeOH} / \alpha, \alpha^{\prime}, \alpha^{\prime \prime}-$ trifluoro toluene, $1: 1(\mathrm{v} / \mathrm{v})$, reaction time $=90 \mathrm{~min}, 30$ bar CO. ${ }^{b}$ Data taken from ref 18 .

when they were dissolved in the reaction medium comprising $\mathrm{MeOH} / \alpha, \alpha^{\prime}, \alpha^{\prime \prime}$-trifluorotoluene, $p$-toluenesulfonic acid, water, and styrene. Whereas for complexes $\mathbf{1}$ and $\mathbf{5}$ the color of the solution immediately turned orange-red, for 3 the solution became only slightly orange colored. For precursors $\mathbf{2}$ and $\mathbf{4}$ the solution stayed light yellow. This could indicate that from the different complexes different intermediates are formed in varying concentrations.

To see if a palladium-hydride species is indeed formed, we conducted a NMR experiment. A solution of $p$-toluenesulfonic acid (3 equiv with respect to palladium) in $\mathrm{MeOH}-d_{4}$ was added to complex 5 . The initial gray suspension became a clear dark red solution in about 1 min. After transfer to a NMR tube a ${ }^{1} \mathrm{H}$ NMR spectrum (at $500 \mathrm{MHz}$, ambient temperature) was recorded, showing the presence of a broad doublet centered at $-6.88 \mathrm{ppm}\left({ }^{2} J\left({ }^{1} \mathrm{H}-{ }^{31} \mathrm{P}\right)=175 \mathrm{~Hz}\right)$. This indicates that a palladium-hydride complex is formed with a cis bis-phosphine configuration. ${ }^{30,37}$ In its ${ }^{31} \mathrm{P}$ $\left\{{ }^{1} \mathrm{H}\right\} \mathrm{NMR}$ spectrum a broad singlet at $28.43 \mathrm{ppm}$ was visible. When a ${ }^{1} \mathrm{H}\left\{{ }^{31} \mathrm{P}\right\}$ NMR spectrum was measured, the broad doublet in the ${ }^{1} \mathrm{H}$ NMR spectrum collapsed to one broad singlet centered at $-6.89 \mathrm{ppm}$.

For complexes $\mathbf{1}$ and $\mathbf{5}$ we observed that, after ca. 70 min reaction time, extensive decomposition of the catalyst to palladium black took place. Hence, we also performed catalysis with these two complexes at $60{ }^{\circ} \mathrm{C}$ instead of $80{ }^{\circ} \mathrm{C}$, under otherwise identical conditions. Performing catalysis at a lower temperature would hopefully lead to less decomposition of the palladium complex and might also have a beneficial effect on the $i: n$ ratio, as has already been shown previously. ${ }^{38,39}$ For comparison we also used the catalyst precursor $[\mathrm{Pd}$ $\left.(\mathrm{OAc})_{2}\left(\mathrm{PPh}_{3}\right)_{2}\right]$ at $60{ }^{\circ} \mathrm{C}$. The results of the experiments are given in Table 3.

For all three complexes we see that the conversion is significantly decreased at this lower temperature. The two zerovalent palladium complexes, however, show a smaller decrease in activity when compared with $[\mathrm{Pd}$ $\left.(\mathrm{OAc})_{2}\left(\mathrm{PPh}_{3}\right)_{2}\right]$ (ca. $20-25 \%$ decrease for 1 and $\mathbf{5}$ vs $55 \%$ decrease in conversion for $\left[\mathrm{Pd}(\mathrm{OAc})_{2}\left(\mathrm{PPh}_{3}\right)_{2}\right]$. Furthermore, upon opening the autoclave after reaction the presence of palladium black was not observed. This indicates that at these lower temperatures the catalyst is much more stable. ${ }^{40}$ The $i: n$ ratio in all three experi-

(37) For values of ${ }^{1} \mathrm{H}$ NMR shifts for the palladium-hydride resonance, see: (a) Reference 34. (b) Reference 36. (c) Perez, P. J.; Calabrese, J. C.; Bunel, E. E. Organometallics 2001, 20, 337.

(38) Girones, J.; Duran, J.; Polo, A.; Real, J. J. Mol. Catal. A: Chem. 2002, 1 .

(39) Seayad, A.; Kelkar, A. A.; Chaudhari, R. V.; Toniolo, L. Ind. Eng. Chem. Res. 1998, 37, 2180 .

(40) The orange-red solution collected from the autoclave quickly turned dark-red/brown and gave palladium black deposition when exposed to air for a few minutes. 
Table 4. Results for Methoxycarbonylation of Styrene with 7 and $\left.\left[\mathrm{Pd}(\mathrm{OAc})_{2}\left(\mathrm{P}_{\{} \mathrm{C}_{6} \mathrm{H}_{4}-\mathrm{p}-\mathrm{SiMe}_{2}\left(\mathrm{CH}_{2} \mathrm{CH}_{2} \mathrm{C}_{6} \mathrm{~F}_{13}\right)\right\}_{3}\right)_{2}\right]$ as the Precursor Complexes ${ }^{a}$

\begin{tabular}{|c|c|c|c|c|}
\hline entry & complex & time $(\min )$ & conversion $(\%)$ & $i: n$ \\
\hline 1 & 7 & 60 & 25 & $53: 47$ \\
\hline 2 & 7 & 120 & 42 & $53: 47$ \\
\hline 3 & 7 & 180 & 45 & $51: 49$ \\
\hline 4 & 7 & 180 & $17^{b}$ & $72: 28$ \\
\hline 5 & {$\left[\mathrm{Pd}(\mathrm{OAc})_{2}\left(\mathrm{P}\left\{\mathrm{C}_{6} \mathrm{H}_{4}-p-\mathrm{SiMe}_{2}\left(\mathrm{CH}_{2} \mathrm{CH}_{2} \mathrm{C}_{6} \mathrm{~F}_{13}\right)\right\}_{3}\right)_{2}\right]^{c}$} & 60 & 17 & $54: 46$ \\
\hline 6 & {$\left[\mathrm{Pd}(\mathrm{OAc})_{2}\left(\mathrm{P}\left\{\mathrm{C}_{6} \mathrm{H}_{4}-p-\mathrm{SiMe}_{2}\left(\mathrm{CH}_{2} \mathrm{CH}_{2} \mathrm{C}_{6} \mathrm{~F}_{13}\right)\right\}_{3}\right)_{2}\right]^{c}$} & 120 & 45 & $53: 47$ \\
\hline 7 & {$\left[\mathrm{Pd}(\mathrm{OAc})_{2}\left(\mathrm{P}\left\{\mathrm{C}_{6} \mathrm{H}_{4}-p-\mathrm{SiMe}_{2}\left(\mathrm{CH}_{2} \mathrm{CH}_{2} \mathrm{C}_{6} \mathrm{~F}_{13}\right)\right\}_{3}\right)_{2}\right]^{c}$} & 180 & 68 & $53: 47$ \\
\hline 8 & {$\left[\mathrm{Pd}(\mathrm{OAc})_{2}\left(\mathrm{P}\left\{\mathrm{C}_{6} \mathrm{H}_{4}-p-\mathrm{SiMe}_{2}\left(\mathrm{CH}_{2} \mathrm{CH}_{2} \mathrm{C}_{6} \mathrm{~F}_{13}\right)\right\}_{3}\right)_{2}\right]^{c}$} & 180 & $20^{b}$ & $70: 30$ \\
\hline
\end{tabular}

${ }^{a}$ General conditions: $[\mathrm{Pd}]=2 \mu \mathrm{mol} / \mathrm{mL}, \mathrm{Pd}$ :styrene: $\mathrm{HO}_{3} \mathrm{SC}_{6} \mathrm{H}_{4}-p$ - $\mathrm{Me}\left(p\right.$-tsaH): $\mathrm{H}_{2} \mathrm{O}=1: 150: 30: 600$, solvent $=\mathrm{MeOH} /$ trifluoro toluene, 1:1 (v/v), 30 bar CO, $T=80^{\circ} \mathrm{C} .{ }^{b}$ At $60{ }^{\circ} \mathrm{C} .{ }^{c}$ Data taken from ref 18.

ments is different from those obtained in the experiments at $80^{\circ} \mathrm{C}$ and displays a slightly higher selectivity toward the branched ( $i$ ) product.

The new fluorous complex $\mathbf{7}$ was also tested as a possible precursor complex for the methoxycarbonylation of styrene, using the same conditions as described above. For comparison reasons results obtained previously with the complex $\left[\mathrm{Pd}(\mathrm{OAc})_{2}\left(\mathrm{P}\left\{\mathrm{C}_{6} \mathrm{H}_{4}-p-\mathrm{SiMe}_{2}-\right.\right.\right.$ $\left.\left.\left.\left(\mathrm{CH}_{2} \mathrm{CH}_{2} \mathrm{C}_{6} \mathrm{~F}_{13}\right)\right\}_{3}\right)_{2}\right]$ are also given in Table 4.

It is obvious that although $\mathbf{7}$ can be used as a precursor for this catalytic reaction, the activity obtained was quite low, especially compared to the conversions obtained with complexes $\mathbf{1}$ and $\mathbf{5}$. When we compare the data acquired for $\mathbf{7}$ with the results obtained for the complex $\left[\mathrm{Pd}(\mathrm{OAc})_{2}\left(\mathrm{P}_{2} \mathrm{C}_{6} \mathrm{H}_{4}-p-\mathrm{SiMe}_{2}\left(\mathrm{CH}_{2}-\right.\right.\right.$ $\left.\left.\left.\mathrm{CH}_{2} \mathrm{C}_{6} \mathrm{~F}_{13}\right)\right\}_{3}\right)_{2}$, ${ }^{18}$ in the first hour with complex $\mathbf{7}$ a higher conversion is obtained as compared to $\left[\mathrm{Pd}(\mathrm{OAc})_{2^{-}}\right.$ $\left.\left(\mathrm{P}\left\{\mathrm{C}_{6} \mathrm{H}_{4}-p-\mathrm{SiMe}_{2}\left(\mathrm{CH}_{2} \mathrm{CH}_{2} \mathrm{C}_{6} \mathrm{~F}_{13}\right)\right\}_{3}\right)_{2}\right]$. After $2 \mathrm{~h}$ reaction time conversion and selectivity are the same for both complexes. Complex 7, however, only shows a marginal increase in conversion (from 42 to $45 \%$ ) after $3 \mathrm{~h}$ of reaction when compared with the fluorous palladium acetate complex (68\% conversion after $180 \mathrm{~min}$ ) at 80 ${ }^{\circ} \mathrm{C}$. The selectivity for both complexes was the same within margin of error. This lower activity with $\mathbf{7}$ after more than $2 \mathrm{~h}$ reaction time is probably caused by extensive catalyst decomposition, which is also evident when the reaction mixture was visually inspected during catalysis. The initial orange-red solution present gradually lost its color during the progress of the reaction and the formation of palladium black was observed. When the autoclave contents were collected afterward, likewise a large amount of palladium black was present. Although this was also observed for the catalysts with $\mathrm{PPh}_{3}$ as ligand, decoloration of the reaction medium and deposition of palladium black was only observed at the late stages of the reaction (after ca. $70 \mathrm{~min}$ ). This means that the catalyst with the fluorous phosphines is less stable than the catalyst with $\mathrm{PPh}_{3}$ under these conditions.

When catalysis with 7 was performed at $60^{\circ} \mathrm{C}$ instead of $80^{\circ} \mathrm{C}$, some conversion was observed (entry 4 in Table 4), but this was low when compared to $\mathbf{1}$ and $\mathbf{5}$. The catalyst, however, appeared to be more stable at this lower temperature: no decoloration of the reaction medium was observed and no palladium black formation was initially present when the autoclave was opened afterward. ${ }^{40}$ When the reaction was performed at $60^{\circ} \mathrm{C}$, both 7 and $\left.\left[\mathrm{Pd}(\mathrm{OAc})_{2}\left(\mathrm{P}_{2} \mathrm{C}_{6} \mathrm{H}_{4}-p-\mathrm{SiMe}_{2}\left(\mathrm{CH}_{2} \mathrm{CH}_{2} \mathrm{C}_{6} \mathrm{~F}_{13}\right)\right\}_{3}\right)_{2}\right]$ had almost the same activity and selectivity after 180 min reaction time.

\section{Discussion}

The ${ }^{13} \mathrm{C}\left\{{ }^{1} \mathrm{H}\right\}$ NMR data of the different palladium(0)-alkene complexes show distinct differences. For both $\mathbf{1}$ and $\mathbf{3}$ the patterns observed for the signals of the alkene carbon atoms correspond to the X part of an AAX pattern, as was shown by simulations. The two patterns differed, however, from each other. From the observed ${ }^{13} \mathrm{C}\left\{{ }^{1} \mathrm{H}\right\}$ NMR data of complex 3 and the simulation thereof we can conclude that no interconversion process is occurring. Since both $=\mathrm{CH}$ carbon atoms experience coupling to a cis- and a trans-phosphorus atoms, we observe their signal as the X part of an AA'X pattern, which in the absence of exchange processes gave the pattern as observed in the left side of Figure 2. For complex 1, with maleic anhydride as the alkene, we have shown by simulation of the alkene part of the ${ }^{13} \mathrm{C}$ $\left\{{ }^{1} \mathrm{H}\right\}$ NMR spectrum that this is the X part of an AA' pattern with an exchange process present. With the current data, however, we cannot say which process is occurring. ${ }^{41}$ The exchange process leads to the observation of a more complicated multiplet pattern (right side of Figure 2).

This difference between complexes $\mathbf{1}$ and $\mathbf{3}$ is remarkable, since in the literature is has been reported that fumaronitrile and maleic anhydride have similar electronwithdrawing abilities, so that their coordinating strength is also the same. ${ }^{22,42,43}$ We would therefore expect similar resonance patterns for the alkene carbon atoms in their ${ }^{13} \mathrm{C}\left\{{ }^{1} \mathrm{H}\right\}$ NMR spectra. A reason could be that for maleic anhydride, which is a cis-alkene, rotation of the alkene around the palladium $(\mathrm{C}=\mathrm{C})$ bond is easier than for fumaronitrile (a trans-alkene). It has been reported by several researchers that rotation of the alkene around the metal $(\mathrm{C}=\mathrm{C})$ bond depends among others on the steric bulk at the metal center. ${ }^{41 a, c, d}$ It has been shown that in certain cases only the complexes having a cis-alkene in their coordination sphere show rotational behavior of the alkene around the $\operatorname{metal}(\mathrm{C}=$

(41) In the literature several exchange processes for such complexes have been reported. One route is the dissociation/reassociation route, whereby the alkene dissociates from the metal center and then reassociates again; see ref 22 . The other route is the rotation of the alkene around the palladium $(\mathrm{C}=\mathrm{C})$ bond. For some examples in the literature, see: (a) Gómez-de la Torre, F.; Jalón, F. A.; López-Agenjo, A.; Manzano, B. R.; Rodríguez, A.; Sturm, T.; Wassensteiner, W.; Martínez-Ripoll, M. Organometallics 1998, 17, 4634. (b) Manzano, B R.; Jalón, F. A.; Gómez-de la Torre, F.; López-Agenjo, A. M.; Rodríguez, A. M.; Mereiter, K.; Weissensteiner, W.; Sturm, T. Organometallics 2002, 21, 789. (c) van Asselt, R.; Elsevier, C. J. Inorg. Chem. 1994, 33, 1521. (d) Albright, T. A.; Hoffmann, R.; Thibeault, J. C.; Thorn, D. L. J. Am. Chem. Soc. 1979, 101, 3801.

(42) Canovese, L.; Visentin, F.; Uguagliati, P.; Crociani, B. J. Chem. Soc., Dalton Trans. 1996, 1921.

(43) Ito, Ts.; Hasegawa, S.; Takahashi, Y.; Ishii, Y. J. Organomet. Chem. 1974, 73, 401. 
C) bond. This could very well apply here as well, but further investigations would be necessary in order to be certain.

In the ${ }^{1} \mathrm{H}$ NMR spectrum (at ambient temperature) of the palladium ethene complex $\mathbf{5}$ we observed broad singlets for the alkene signal as well as for the signals of the $\mathrm{PPh}_{3}$ groups. This is caused by the intermolecular exchange between free ethene in solution and coordinated ethene on the palladium center, as has been previously observed for the complex $\left[\mathrm{Pd}\left(\right.\right.$ diop)(ethene)]. ${ }^{17}$ At low temperature the exchange broadened signal in the ${ }^{1} \mathrm{H}$ NMR spectrum is split up into separate signals for free and coordinated ethene. These signals are still broad singlets at $-60{ }^{\circ} \mathrm{C}$, showing that the exchange proces is rapid, even at such a low temperature. This was further corroborated by the observation that at ambient temperature as well as at $-60{ }^{\circ} \mathrm{C}$ no signal for the alkene carbon atoms could be detected in the ${ }^{13} \mathrm{C}$ $\left\{{ }^{1} \mathrm{H}\right\}$ NMR spectrum.

The reaction of $\mathbf{5}$ with $p$-toluenesulfonic acid under controlled conditions has shown that a palladiumhydride complex is indeed formed and that its formation is rapid. We can assume that for the different complexes such a palladium-hydride species is also formed when the catalyst precursor is dissolved in the reaction medium (which contains among others $p$-toluenesulfonic acid). The data from Table 2 show, however, that there is a big influence of the alkene present in the precursor complex on the observed activity of the catalyst. The complexes with the alkene that is relatively weakly bonded (ethene) show the highest activity, whereas the complex with a strongly binding alkene (TCNE) showed almost no activity. The other alkenes fall nicely between these two extremes. Maleic anhydride is an exception here, since it gave the same activity as the ethene complex, although it is reported to have the same coordination strength as fumaronitrile. These observations suggest that the presence of different alkenes influences the rate-determining step (or the preceding step) of the reaction.

What exactly the rate-determining step is we cannot say. There are, however, several likely possibilities. The first one is that when the palladium(0)-alkene complexes are used, the rate-determining step is the formation of the palladium-hydride complex, which is the actual active species. When a strongly coordinated alkene is present, the formation of a $\left[\mathrm{PdL}_{2}\right]$ species (by dissociation of the alkene), which is supposed to react with the acid in a next step to give the palladium(II)hydride complex, is hindered. In this way, only a varying amount of precatalyst is converted into an active species, depending on the alkene palladium bonding, leading for the stronger binding alkenes to the low conversion observed. This does not explain, however, why complex $\mathbf{1}$ gave such a high activity, while complex $\mathbf{3}$ gave a much lower activity, despite that maleic anhydride and fumaronitrile have a similar coordinating strength.

The second reason could be that in all cases the active species is formed quickly, regardless of which precatalyst is used, but the alkene released competes with styrene for coordination to the palladium center in the rate-determining step of the catalytic cycle itself. For alkenes that have a higher coordinating strength, we would then expect a lower conversion (in the same reaction time). Although such a trend is clearly visible

\section{Scheme 6. Catalytic Cycle for Methoxycarbonylation of Styrene Using a $\left[\mathrm{Pd}(0)\left(\mathrm{PAr}_{3}\right)_{2}(\right.$ alkene $\left.)\right]$ Complex as the Precursor ${ }^{a}$}

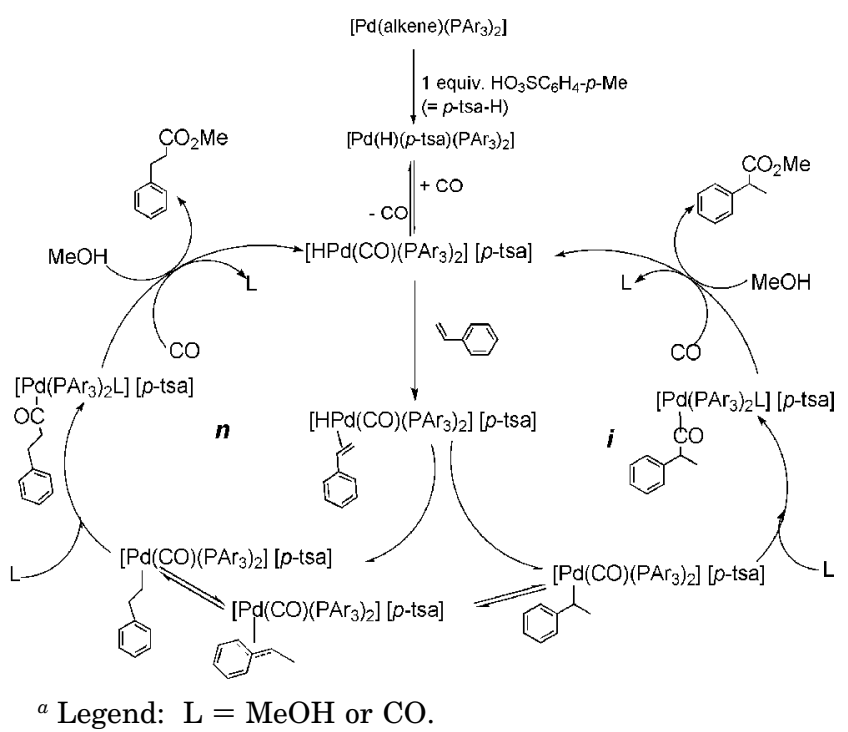

from the current data, again maleic anhydride does not show the behavior that we would expect based on coordinating strength only. More detailed investigations into the behavior of the complexes, and especially that of complex 1, are necessary to obtain a full understanding.

When we compare the results for the palladium $(0)$ alkene complexes with those for $\left[\mathrm{Pd}(\mathrm{OAc})_{2}\left(\mathrm{PPh}_{3}\right)_{2}\right]$ as the precursor, we see that the best palladium(0)-alkene complexes (1 and 5) compare quite favorably with this complex, in terms of both activity and selectivity. We can presume therefore that for the palladium(0)-alkene complexes the same catalytic cycle as proposed for $[\mathrm{Pd}$ $\left.(\mathrm{OAc})_{2}\left(\mathrm{PPh}_{3}\right)_{2}\right]$ is operational (Scheme 6). ${ }^{33}$

Fluorous precursor palladium(0) complex $\mathbf{7}$ gave a lower conversion when compared with its nonfluorous analogue 1. A similar effect was already observed in a previous study, where we compared the complexes [Pd$\left.(\mathrm{OAc})_{2}\left(\mathrm{P}\left\{\mathrm{C}_{6} \mathrm{H}_{4}-p-\mathrm{SiMe}_{2}\left(\mathrm{CH}_{2} \mathrm{CH}_{2} \mathrm{C}_{6} \mathrm{~F}_{13}\right)\right\}_{3}\right)_{2}\right]$ and $[\mathrm{Pd}-$ $\left.(\mathrm{OAc})_{2}\left(\mathrm{PPh}_{3}\right)_{2}\right] .{ }^{18}$ Apparently, the introduction of fluorous phosphines into catalysts for the methoxycarbonylation of styrene has a negative effect on the activity. However, for $\mathbf{7}$ a slightly higher selectivity toward the branched product was observed when compared with $\mathbf{1}$, which is again in line with the observations made when the complexes $\left[\mathrm{Pd}(\mathrm{OAc})_{2}\left(\mathrm{PAr}_{3}\right)_{2}\right]$ were used as catalyst precursors.

Between palladium $(0)$ complex $\mathbf{7}$ and $\left[\mathrm{Pd}(\mathrm{OAc})_{2^{-}}\right.$ $\left.\left(\mathrm{P}\left\{\mathrm{C}_{6} \mathrm{H}_{4}-p-\mathrm{SiMe}_{2}\left(\mathrm{CH}_{2} \mathrm{CH}_{2} \mathrm{C}_{6} \mathrm{~F}_{13}\right)\right\}_{3}\right)_{2}\right]$ as the catalyst precursor differences were also observed. During the first $2 \mathrm{~h}$ of catalysis there is no difference between the use of $\mathbf{7}$ and $\left.\left[\mathrm{Pd}(\mathrm{OAc})_{2}\left(\mathrm{P}_{2} \mathrm{C}_{6} \mathrm{H}_{4}-p-\mathrm{SiMe}_{2}\left(\mathrm{CH}_{2} \mathrm{CH}_{2} \mathrm{C}_{6} \mathrm{~F}_{13}\right)\right\}_{3}\right)_{2}\right]$, but after that time period $\mathbf{7}$ gave almost no further activity, whereas with $\left[\mathrm{Pd}(\mathrm{OAc})_{2}\left(\mathrm{P}\left\{\mathrm{C}_{6} \mathrm{H}_{4}-p-\mathrm{SiMe}_{2}\left(\mathrm{CH}_{2}-\right.\right.\right.\right.$ $\left.\left.\left.\left.\mathrm{CH}_{2} \mathrm{C}_{6} \mathrm{~F}_{13}\right)\right\}_{3}\right)_{2}\right]$ still appreciable activity was observed until about $3 \mathrm{~h}$ reaction time. For the palladium(II) complex we have already shown that there is an equilibrium between $\left[\mathrm{Pd}(\mathrm{OAc})_{2}\left(\mathrm{P}\left\{\mathrm{C}_{6} \mathrm{H}_{4}-p-\mathrm{SiMe}_{2}\left(\mathrm{CH}_{2}-\right.\right.\right.\right.$ $\left.\left.\left.\left.\mathrm{CH}_{2} \mathrm{C}_{6} \mathrm{~F}_{13}\right)\right\}_{3}\right)_{2}\right]$ and the dimeric complex $\left[\mathrm{Pd}(\mathrm{OAc})_{2^{-}}\right.$ $\left.\left(\mathrm{P}\left\{\mathrm{C}_{6} \mathrm{H}_{4}-p-\mathrm{SiMe}_{2}\left(\mathrm{CH}_{2} \mathrm{CH}_{2} \mathrm{C}_{6} \mathrm{~F}_{13}\right)\right\}_{3}\right)\right]_{2}$ and free phosphine in solution. This dimeric complex is slowly converted into active species during the reaction time. This makes sure that fresh catalyst is present in solution, also after 
$2 \mathrm{~h}$ of catalysis. For $\mathbf{7}$ such an equilibrium reaction is not present; here the catalyst precursor is converted straightaway into catalytically active species. We can therefore assume, also because we observe extensive formation of palladium black with $\mathbf{7}$ as the precursor, that after $2 \mathrm{~h}$ most of the catalyst is destroyed.

\section{Conclusions}

A series of zerovalent palladium(0)-alkene bis(triphenylphosphine) complexes was synthesized and characterized. In the ${ }^{13} \mathrm{C}\left\{{ }^{1} \mathrm{H}\right\}$ NMR spectra of the complexes it was observed that the alkene carbon signals of coordinated fumaronitrile and maleic anhydride show different patterns. The complexes were tested as catalyst precursors for the methoxycarbonylation of styrene at $80{ }^{\circ} \mathrm{C}$, from which the following ranking in activity was observed: ethene $\approx$ maleic acid anhydride > fumaronitrile $>$ benzoquinone $>$ tetracyanoethylene. Catalysis at lower temperatures gave a moderate drop in conversion, but a higher selectivity toward the branched product. ${ }^{1} \mathrm{H}$ NMR experiments with the palladium-ethene complex showed that the starting alkene complex reacts with $p$-toluenesulfonic acid to give a palladium-hydride complex. The complex $\left[\mathrm{Pd}(0)\left(\mathrm{P}\left\{\mathrm{C}_{6} \mathrm{H}_{4}-\right.\right.\right.$ $p$-SiMe $\left.\left.{ }_{2}\left(\mathrm{CH}_{2} \mathrm{CH}_{2} \mathrm{C}_{6} \mathrm{~F}_{13}\right)\right\}_{3}\right)_{2}$ (maleic anhydride)] was also synthesized, characterized, and tested as a catalyst precursor for this reaction. It was found to be less active than its nonfluorous counterpart and to rapidly decompose to palladium black under reaction conditions (80 $\left.{ }^{\circ} \mathrm{C}\right)$. This decomposition could be prevented by lowering the reaction temperature, which also has a beneficial effect on selectivity toward the branched product.

The results presented here show that palladium(0)alkene complexes are viable precursors for the methoxycarbonylation of styrene and that the fluorous derivatives could be successfully synthesized and applied as precursors as well. Before application in FBS is feasible, issues concerning catalyst stability under reaction conditions and recycling should be further investigated. Also, further investigations on the catalytic cycle are worthwhile, for instance by examining the kinetics, order in styrene, and the influence of alkene released from the precursor complex.

\section{Experimental Section}

General Procedures. All experimental work was carried out in Schlenk type vessels under a $\mathrm{N}_{2}$ atmosphere unless stated otherwise. Diethyl ether, $n$-pentane, $n$-hexane, THF, and toluene were dried and distilled from sodium. Acetone was distilled from $\mathrm{B}_{2} \mathrm{O}_{3}$. $\mathrm{MeOH}$ was distilled from $\mathrm{Mg}(\mathrm{OMe})_{2}$. $\alpha, \alpha^{\prime}, \alpha^{\prime \prime}$-Trifluorotoluene was degassed via freeze-pumpthaw cycles (3 times) and stored on molecular sieves. $\left[\mathrm{Pd}_{2-}\right.$ $\left.(\mathrm{dba})_{3} \cdot \mathrm{dba}\right],{ }^{1}\left[\mathrm{Pd}\left(\mathrm{PPh}_{3}\right)_{2}(\mathrm{MA})\right],{ }^{7} \quad\left[\mathrm{Pd}\left(\mathrm{PPh}_{3}\right)_{2}(\mathrm{TCNE})\right],{ }^{7} \quad[\mathrm{Pd}-$ $\left.\left(\mathrm{PPh}_{3}\right)_{2}(\mathrm{BQ})\right],{ }^{19}\left[\mathrm{Pd}\left(\mathrm{PPh}_{3}\right)_{2}\left(\mathrm{C}_{2} \mathrm{H}_{4}\right)\right],{ }^{12}$ and $\mathrm{P}\left\{\mathrm{C}_{6} \mathrm{H}_{4}-p-\mathrm{SiMe}_{2}\left(\mathrm{CH}_{2^{-}}\right.\right.$ $\left.\left.\mathrm{CH}_{2} \mathrm{C}_{6} \mathrm{~F}_{13}\right)\right\}_{3}{ }^{44}$ were synthesized as reported. $\mathrm{PPh}_{3}$, [AlEt $\mathrm{Al}_{2}$ (OEt) $]_{2}$ (Aldrich), $n$-decane, $p$-toluenesulfonic acid monohydrate (Acros), and $\left[\mathrm{Pd}(\text { acetylacetonato })_{2}\right]$ (Strem) were used as received. Styrene (Acros) was purified by flash chromatography (neutral Alumina, Fluka) prior to use. $\mathrm{C}_{2} \mathrm{H}_{4}$ (Praxair, grade 4.0) and $\mathrm{CO}$ (Praxair, >99.9\%) were used as received. $\mathrm{CDCl}_{3}$, $\mathrm{CD}_{2} \mathrm{Cl}_{2}, \mathrm{C}_{6} \mathrm{D}_{6}$, and toluene- $d_{8}$ (Cambridge Isotope Laboratories) were degassed and stored on molecular sieves under $\mathrm{N}_{2} \cdot{ }^{1} \mathrm{H}$, ${ }^{13} \mathrm{C}\left\{{ }^{1} \mathrm{H}\right\},{ }^{19} \mathrm{~F}$, and ${ }^{31} \mathrm{P}\left\{{ }^{1} \mathrm{H}\right\}$ NMR spectra were recorded on a $300 \mathrm{MHz}$ Varian Mercury-VxWorks, a Varian-INOVA 500, and a Bruker DRX300 at ambient temperature unless stated

(44) Richter, B.; de Wolf, A. C. A.; van Koten, G.; Deelman, B.-J. J. Org. Chem. 2000, 65, 3885 . otherwise. Chemical shifts are referenced internally against residual solvent signal $\left({ }^{1} \mathrm{H},{ }^{13} \mathrm{C}\right)$ or externally against $\mathrm{CFCl}_{3}$ $\left({ }^{19} \mathrm{~F}\right)$ or $85 \% \mathrm{H}_{3} \mathrm{PO}_{4}\left({ }^{31} \mathrm{P}\right)$. Abbreviations used: $\mathrm{s}=$ singlet, $\mathrm{d}=$ doublet, $\mathrm{t}=$ triplet, $\mathrm{vt}=$ virtual triplet, $\mathrm{m}=$ multiplet. $\mathrm{GC}$ analyses were performed on a Varian 3300 gas chromatograph equipped with a J\&W Scientific Inc. DB-5 column (30 m, 0.320 $\mathrm{mm}$ internal diameter) and a FID detector $\left(280{ }^{\circ} \mathrm{C}\right)$, using $\mathrm{N}_{2}$ as the carrier gas and attached to a Varian 4400 integrator. Elemental analyses were carried out by H. Kolbe Mikroanalytisch Laboratorium, Müllheim an der Ruhr.

Autoclaves. Two autoclaves were employed for all catalytic reactions. One was a normal Hastelloy autoclave with a volume of $100 \mathrm{~mL}$. Stirring was achieved with a magnetic stirring bar, and heating was accomplished with a heating mantle. To exclude contamination with metallic palladium or other residues from the inner wall, a glass insert was employed in all reactions. The second autoclave was a home-built stainless steel (Hastelloy) autoclave with a volume of $50 \mathrm{~mL} .{ }^{45}$ It is equipped with a pressure transducer (Kulite), thermocouples in the wall and interior of the autoclave, four heating rods drilled into the mantle, a rupture disk assembly (set at 250 bar), an injection port, and two borosilicate (Maxos 200) windows to allow visual inspection of the contents. The temperature was controlled for both autoclaves to be $\pm 2{ }^{\circ} \mathrm{C}$ of the desired reaction temperature.

[Palladium $(\mathbf{0})\left(\mathbf{P P h}_{3}\right)_{2}$ (maleic anhydride)] (1). Following the procedure as described by Vrieze et al., ${ }^{7}$ the title compound was prepared from $[\mathrm{Pd}(0)(t-\mathrm{BuDAB})(\mathrm{MA})] \mathbf{1}(0.71 \mathrm{~g}, 1.90 \mathrm{mmol})$ and triphenylphosphine $(1.30 \mathrm{~g}, 4.94 \mathrm{mmol})$ and obtained as a yellow-green solid $(0.96 \mathrm{~g}, 1.90 \mathrm{mmol}, 100 \%$ based on $[\operatorname{Pd}(0)$ $(t$-BuDAB $)(\mathrm{MA})]) .{ }^{1} \mathrm{H}$ NMR data were in accordance with those reported.

${ }^{13} \mathrm{C}\left\{{ }^{1} \mathrm{H}\right\} \mathrm{NMR}\left(\mathrm{CD}_{2} \mathrm{Cl}_{2}, 75.5 \mathrm{MHz}\right): \delta 56.2\left(\mathrm{~m},{ }^{2} \boldsymbol{J}_{\mathrm{C}, \mathrm{P}}=20.2\right.$ $\mathrm{Hz}(\mathrm{t}),{ }^{2} J_{\mathrm{C}, \mathrm{P}}=22.7 \mathrm{MHz}(\mathrm{d}), C \mathrm{H}$ of MA), 128.8 (vt, $J_{\mathrm{C}, \mathrm{P}}=9.4$ $\mathrm{Hz}, m-\mathrm{C} \mathrm{PPh}$ ), $130.0\left(\mathrm{~s}, p-\mathrm{C} \mathrm{PPh}_{3}\right.$ ), 132.3 (vt, $J_{\mathrm{C}, \mathrm{P}}=\mathrm{Hz}$, ipso-C $\mathrm{PPh}_{3}$ ), 134.1 (vt, $J_{\mathrm{C}, \mathrm{P}}=14.2 \mathrm{~Hz}, o-\mathrm{C} \mathrm{PPh}$ ), $170.5(\mathrm{~s}, C=\mathrm{O}$ of MA). ${ }^{31} \mathrm{P}\left\{{ }^{1} \mathrm{H}\right\}$ NMR $\left(\mathrm{CD}_{2} \mathrm{Cl}_{2}, 121.5 \mathrm{MHz}\right): \delta 27.37(\mathrm{~s})$.

[Palladium(0) $\left(\mathbf{P P h}_{3}\right)_{2}$ (tetracyanoethylene)] (2). Following the experimental procedure as described by Vrieze et al., ${ }^{7}$ the title compound was synthesized from $[\mathrm{Pd}(0)(t$-BuDAB)(TCNE)] (0.72 g, $1.79 \mathrm{mmol})$ and triphenylphosphine (1.22 g, $4.65 \mathrm{mmol})$ and isolated as a green solid (1.36 g, $1.79 \mathrm{mmol}$, $100 \%$ based on $[\mathrm{Pd}(0)(t$-BuDAB $)(\mathrm{TCNE})]) .{ }^{1} \mathrm{H}$ NMR data were in accordance with those reported.

${ }^{13} \mathrm{C}\left\{{ }^{1} \mathrm{H}\right\} \mathrm{NMR}\left(\mathrm{CDCl}_{3}, 75.5 \mathrm{MHz}\right): \delta 26.11\left(\mathrm{vt},{ }^{2} J_{\mathrm{C}, \mathrm{P}}=22.5\right.$ $\mathrm{Hz}, C=C \mathrm{TCNE}), 113.79\left(\mathrm{vt},{ }^{3} J_{\mathrm{C}, \mathrm{P}}=3.7 \mathrm{~Hz}, C \mathrm{~N}\right), 129.39(\mathrm{vt}$, $\left.J_{\mathrm{C}, \mathrm{P}}=10.8 \mathrm{~Hz}, m-\mathrm{C} \mathrm{PPh}_{3}\right), 131.56\left(\mathrm{~s}, p-\mathrm{C} \mathrm{PPh}_{3}\right.$ ), 134.08 (vt, $J_{\mathrm{C}, \mathrm{P}}=12.8 \mathrm{~Hz}, o-\mathrm{C} \mathrm{PPh}_{3}$ ). The signal for ipso-C of $\mathrm{PPh}_{3}$ was not observed. ${ }^{31} \mathrm{P}\left\{{ }^{1} \mathrm{H}\right\}$ NMR $\left(\mathrm{CDCl}_{3}, 121.5 \mathrm{MHz}\right): \delta 23.86(\mathrm{~s})$.

[Palladium $(\mathbf{0})\left(\mathbf{P P h}_{3}\right)_{2}$ (fumaronitrile)] (3). A procedure similar to the one used for $\mathbf{1}$ and $\mathbf{2}$ was used. ${ }^{7}$ To a solution of $6(1.73 \mathrm{mmol})$ in a Schlenk vessel in dry acetone $(20 \mathrm{~mL})$ was added triphenylphosphine (1.20 g, $4.50 \mathrm{mmol})$. After stirring for $2 \mathrm{~h}$ the reaction mixture was filtered on Celite and evaporated to dryness to give an off-white solid in quantitative yield ( $1.23 \mathrm{~g}, 1.73 \mathrm{mmol}, 100 \%$ based on 6 ). ${ }^{1} \mathrm{H}$ NMR data were in accordance with previously reported values.

${ }^{13} \mathrm{C}\left\{{ }^{1} \mathrm{H}\right\} \mathrm{NMR}\left(\mathrm{CD}_{2} \mathrm{Cl}_{2}, 75.5 \mathrm{MHz}\right): \delta 34.6\left(\mathrm{dd},{ }^{2} J_{\mathrm{C}, \mathrm{P}}=6.6\right.$ $\left.\mathrm{Hz},{ }^{2} J_{\mathrm{C}, \mathrm{P}}=36.8 \mathrm{~Hz}, C \mathrm{H}(\mathrm{CN})\right), \delta 121.6(\mathrm{t}, \mathrm{CH}(\mathrm{CN})), 128.8(\mathrm{~m}$, $C$-aryl $\mathrm{PPh}_{3}$ ), 130.3 (s, $p$-C $\left.\mathrm{PPh}_{3}\right), 134.0\left(\mathrm{~m}, C\right.$-aryl $\left.\mathrm{PPh}_{3}\right) .{ }^{31} \mathrm{P}$ $\left\{{ }^{1} \mathrm{H}\right\}$ NMR $\left(\mathrm{CD}_{2} \mathrm{Cl}_{2}, 121.5 \mathrm{MHz}\right): \delta 27.04(\mathrm{~s})$.

[Palladium(0) $\left(\mathbf{P P h}_{3}\right)_{2}$ (p-benzoquinone)] (4). A procedure for related complexes was used. ${ }^{19}$ To a suspension of tetrakistriphenylphosphinepalladium(0) $(120 \mathrm{mg}, 0.10 \mathrm{mmol})$ in dry benzene ( $1 \mathrm{~mL}$ ) was added a solution of benzoquinone $(10.8 \mathrm{mg}, 0.13 \mathrm{mmol})$ in dry benzene $(0.4 \mathrm{~mL})$. The reaction mixture was stirred for $30 \mathrm{~min}$. The clear solution was concentrated to $0.2 \mathrm{~mL}$, and a mixture of ether/hexane $(2: 1)$ was added to obtain a red to orange solid in quantitative yield (76.9 mg, $0.10 \mathrm{mmol}, 100 \%$ based on $\left.\left[\mathrm{Pd}\left(\mathrm{PPh}_{3}\right)_{4}\right]\right)$.

(45) For a detailed description see: ref 11, Chapter 2 
${ }^{1} \mathrm{H}$ NMR $\left(\mathrm{C}_{6} \mathrm{D}_{6}, 300.1 \mathrm{MHz}\right): \delta 5.39\left(\mathrm{~d},{ }^{3} J_{\mathrm{H}, \mathrm{P}}=6.6 \mathrm{~Hz}, 4 \mathrm{H}\right.$, BQ), 6.94 (m, 18H, $H$-aryl $\left.\mathrm{PPh}_{3}\right), 7.35$ (m, $12 \mathrm{H}, H$-aryl $\mathrm{PPh}_{3}$ ). ${ }^{13} \mathrm{C}\left\{{ }^{1} \mathrm{H}\right\} \operatorname{NMR}\left(\mathrm{C}_{6} \mathrm{D}_{6}, 75.5 \mathrm{MHz}\right): \delta 104.81\left(\mathrm{vt},{ }^{3} J_{\mathrm{C}, \mathrm{P}}=1.5 \mathrm{~Hz}\right.$, $C \mathrm{H} \mathrm{BQ}$ ), 128.43 (vt, $J_{\mathrm{C}, \mathrm{P}}=9.4 \mathrm{~Hz}, m-\mathrm{C} \mathrm{PPh}$ ), 130.02 (s, $p-\mathrm{C}$ $\mathrm{PPh}_{3}$ ), $133.99\left(\right.$ vt, $\left.J_{\mathrm{C}, \mathrm{P}}=14.4 \mathrm{~Hz}, o-\mathrm{C} \mathrm{PPh}_{3}\right), 185.89(\mathrm{~s}, C=\mathrm{O}$ BQ). ${ }^{31} \mathrm{P}\left\{{ }^{1} \mathrm{H}\right\}$ NMR $\left(\mathrm{C}_{6} \mathrm{D}_{6}, 121.5 \mathrm{MHz}\right): \delta 30.64(\mathrm{~s})$.

[Palladium(0)( $\left(\mathbf{P P h}_{3}\right)_{2}$ (ethene)] (5). Following the procedure as described by de Jongh et al. ${ }^{12}$ the title compound was synthesized from $\left[\mathrm{Pd}(\text { acetylacetonate })_{2}\right](1.00 \mathrm{~g}, 3.28 \mathrm{mmol})$, triphenylphosphine $(1.72 \mathrm{~g}, 6.56 \mathrm{mmol})$, and $\left[\mathrm{Al}(\mathrm{Et})_{2}(\mathrm{OEt})\right]_{2}$ $(4.8 \mathrm{~mL}, 6.50 \mathrm{mmol})$ and isolated as a light gray solid $(0.78 \mathrm{~g}$, $1.18 \mathrm{mmol}, 36 \%$ based on $\left.\left[\operatorname{Pd}(\text { acetylacetonate })_{2}\right]\right)$. Because of the high instability of the complex in solution when no additional ethene is present, NMR spectra were recorded in ethene-saturated toluene- $d_{8}$ and $\mathrm{CD}_{2} \mathrm{Cl}_{2}$.

${ }^{1} \mathrm{H}$ NMR (toluene- $d_{8}, 300.1 \mathrm{MHz}$ ): $\delta 4.09$ (br s, $\mathrm{CH}_{2}$ of ethene), $7.17\left(\mathrm{~m}, 18 \mathrm{H}, \mathrm{PPh}_{3}\right), 7.65$ (br s, $\left.12 \mathrm{H}, \mathrm{PPh}_{3}\right) .{ }^{13} \mathrm{C}\left\{{ }^{1} \mathrm{H}\right\}$ $\operatorname{NMR}\left(\mathrm{CD}_{2} \mathrm{Cl}_{2}, 75.5 \mathrm{MHz},-60{ }^{\circ} \mathrm{C}\right): \delta 127.84\left(\mathrm{~s}, C\right.$-aryl $\left.\mathrm{PPh}_{3}\right)$, $128.62\left(\mathrm{~s}, C\right.$-aryl $\left.\mathrm{PPh}_{3}\right), 133.27\left(\mathrm{vt}, J_{\mathrm{C}, \mathrm{P}}=15.0 \mathrm{~Hz}, o-\mathrm{C} \mathrm{PPh}_{3}\right)$, 137.20 (vt, $J_{\mathrm{C}, \mathrm{P}}=27.4 \mathrm{~Hz}$, ipso-C $\mathrm{PPh}_{3}$ ). The signal for $\mathrm{CH}_{2}$ of ethene was not observed. ${ }^{31} \mathrm{P}\left\{{ }^{1} \mathrm{H}\right\}$ NMR (toluene- $d_{8}, 121.5$ $\left.\mathrm{MHz},-40{ }^{\circ} \mathrm{C}\right): \delta 27.47(\mathrm{~s})$.

[Palladium(0)(tert-butylDAB)(fumaronitrile)] (6). A procedure similar to the one used for $\mathbf{1}$ and $\mathbf{2}$ was used. ${ }^{7}$ To a solution of $\left[\mathrm{Pd}_{2}(\mathrm{dba})_{3} \cdot \mathrm{dba}\right](2.94 \mathrm{mmol})$ and tert-butylDAB $(6.45$ $\mathrm{mmol})$ in a Schlenk vessel in dry acetone $(20 \mathrm{~mL})$ was added fumaronitrile $(0.50 \mathrm{~g}, 6.45 \mathrm{mmol})$. After stirring overnight at room temperature, the reaction mixture was filtered over Celite and evaporated to dryness. The resulting yellow solid was washed with $n$-pentane and dried under vacuum to give a yellow solid $\left(1.74 \mathrm{~g}, 4.94 \mathrm{mmol}, 84 \%\right.$ yield based on $\left[\mathrm{Pd}_{2-}\right.$ $\left.\left.(\mathrm{dba})_{3} \cdot \mathrm{dba}\right]\right)$. Crystals suitable for single-crystal X-ray determination were obtained by slow evaporation of the solvent from a solution of the complex in acetone. Its ${ }^{1} \mathrm{H}$ NMR data were in accordance with those reported earlier in the literature.

${ }^{13} \mathrm{C}\left\{{ }^{1} \mathrm{H}\right\} \mathrm{NMR}\left(\mathrm{CD}_{2} \mathrm{Cl}_{2}, 75.5 \mathrm{MHz}\right): \delta 156.8(C=\mathrm{N}$ imine $)$, $123.4\left(\mathrm{CN}\right.$ fumaronitrile), $62.6(\mathrm{CH}(\mathrm{CN})), 29.7\left(\mathrm{C}\left(\mathrm{CH}_{3}\right)_{3}\right), 18.3$ $\left(\mathrm{CH}_{3}\right)$. FAB MS: $\mathrm{M}^{+}=353.1$.

Crystal Structure Determination of [palladium(0)(tert-butylDAB)(fumaronitrile)] (6). $\mathrm{C}_{14} \mathrm{H}_{22} \mathrm{~N}_{4} \mathrm{Pd}, \mathrm{fw}=$ 352.76 , yellow block, $0.04 \times 0.10 \times 0.40 \mathrm{~mm}^{3}$, monoclinic, space group $C 2 / c$ (no. 15), $a=11.812(5) \AA, b=14.33(3) \AA, c=10.703$ (5) $\AA, \beta=120.42(5)^{\circ}, V=1562(4) \AA^{3}, Z=4, \rho=1.500 \mathrm{~g} / \mathrm{cm}^{3}$, $F(000)=720$. A total of 12527 reflections were measured up to a resolution of $(\sin \theta / \lambda)=0.63 \AA^{-1}$ on a Nonius Kappa CCD diffractometer with rotating anode and Mo $\mathrm{K} \alpha$ radiation (graphite monochromator, $\lambda=0.71073 \AA$ ) at a temperature of 150(2) K. A multiscan absorption correction was applied using SADABS. ${ }^{46}$ The unit cell was obtained using DIRAX, ${ }^{47}$ and data were collected using Collect Software ${ }^{48}$ and integrated using EvalCCD ${ }^{49}$ A total of 1786 reflections were unique $\left(R_{\text {int }}\right.$ $=0.065)$. The structure was solved with DIRDIF9950 and refined using SHELXL97. ${ }^{51}$ Non-hydrogen atoms were refined freely. $\mathrm{H}(6)$ was located in a difference map refined isotropically. All other hydrogen atoms were placed in idealized positions and constrained to ride on their parent atoms $\left(U_{\text {iso- }^{-}}\right.$ $(\mathrm{H})=1.2 U_{\text {iso }}(\mathrm{C})$ for aromatic $\mathrm{H}$ atoms and $U_{\text {iso }}(\mathrm{H})=U_{\text {iso }}(\mathrm{C})$ for all other hydrogen atoms). Refined parameters: $94 . R(I>$ $2 \sigma(I)): R_{1}=0.0325, w R_{2}=0.0720 . R$ (all data): $R_{1}=0.0434$, $w R_{2}=0.0753 . S=1.1$. Weighting scheme $w=1 /\left[\sigma^{2}\left(F_{0}^{2}\right)+\right.$

(46) Bruker. SADABS; Bruker AXS GmbH: Karlsruhe, Germany, 2002.

(47) Duisenberg, A. J. M. J. Appl. Crystallogr. 1992, 25, 92.

(48) Collect Software; Nonius B.V.: Delft, The Netherlands, 1998

(49) Duisenberg, A. J. M.; Kroon-Batenburg, L. M. J.; Schreurs, A. M. M J. Appl. Crystallogr. 2003, 36, 220.

(50) Beurskens, P. T.; Beurskens, G.; de Gelder, R.; García-Granda, S.; Gould, R. O.; Israel, R.; Smits, J. M. M. The DIRDIF99 Program System; Technical Report of the Crystallography Laboratory, University of Nijmegen: The Netherlands, 1999 .

(51) Sheldrick, G. M. SHELXL97, Program for crystal structure refinement; University of Göttingen: Germany, 1997. $\left.(0.0328 P)^{2}+5.2766 P\right]$ where $P=\left(F_{0}^{2}+2 F_{\mathrm{c}}{ }^{2}\right) / 3$. Residual electron density: between -1.19 and $0.72 \mathrm{e} / \AA^{3}$. The drawings, structure calculations, and checking for higher symmetry were performed with the program Platon. ${ }^{52}$

[Palladium(0) $\left(\mathrm{P}\left\{\mathrm{C}_{6} \mathrm{H}_{4}-p-\mathrm{SiMe}_{2}\left(\mathrm{CH}_{2} \mathrm{CH}_{2} \mathrm{C}_{6} \mathrm{~F}_{13}\right)\right\}_{3}\right)_{2}$ (maleic anhydride)] (7). In a Schlenk vessel was weighed $\mathrm{P}\left\{\mathrm{C}_{6} \mathrm{H}_{4}-p-\mathrm{SiMe}_{2}\left(\mathrm{CH}_{2} \mathrm{CH}_{2} \mathrm{C}_{6} \mathrm{~F}_{13}\right)\right\}_{3}(0.89 \mathrm{~g}, 0.60 \mathrm{mmol})$, which was subsequently dissolved in THF $(10 \mathrm{~mL})$. [Palladium(0)(maleic anhydride)(norbornadiene)] ( $89.4 \mathrm{mg}, 0.30 \mathrm{mmol}$ ) was added, and the resulting yellow solution was stirred for $30 \mathrm{~min}$ at ambient temperature. The solution was filtered through Celite to remove metallic palladium, and the filter cake was washed with THF $(2 \times 5 \mathrm{~mL})$. The combined organic layers were evaporated to dryness. The remaining yellow oil was washed with $n$-pentane at $-40{ }^{\circ} \mathrm{C}$ ( 3 times). The final product was obtained as a light yellow solid $(0.51 \mathrm{~g}, 0.16 \mathrm{mmol}, 54 \%$ based on [palladium(0)(maleic anhydride)(norbornadiene)]).

${ }^{1} \mathrm{H}$ NMR $\left(300.1 \mathrm{MHz}, \mathrm{CD}_{2} \mathrm{Cl}_{2}\right): \delta 0.33\left(\mathrm{~s}, 36 \mathrm{H}, \mathrm{SiMe} e_{2}\right), 0.98$ (m, $\left.12 \mathrm{H}, \mathrm{SiCH}_{2} \mathrm{CH}_{2}\right), 2.03\left(\mathrm{~m}, 12 \mathrm{H}, \mathrm{SiCH}_{2} \mathrm{CH}_{2}\right), 4.15\left(\mathrm{~d},{ }^{3} J_{\mathrm{H}, \mathrm{P}}\right.$ $=4.8 \mathrm{~Hz}, \mathrm{CH} \mathrm{MA}), 7.18\left(\mathrm{t}, 10 \mathrm{H}, \mathrm{P}_{-} \mathrm{C}_{6} H_{4}\right), 7.37\left(\mathrm{~d}, 10 \mathrm{H}, \mathrm{P}_{-} \mathrm{C}_{6} \mathrm{H}_{4}\right)$. ${ }^{13} \mathrm{C}\left\{{ }^{1} \mathrm{H}\right\} \mathrm{NMR}\left(\mathrm{CD}_{2} \mathrm{Cl}_{2}, 125.7 \mathrm{MHz}\right): \delta-3.64\left(\mathrm{~s}, \mathrm{SiMe} e_{2}\right), 5.28$ (s, $\left.\mathrm{SiCH}_{2}\right), 26.08\left(\mathrm{t},{ }^{2} J_{\mathrm{C}, \mathrm{F}}=23.5 \mathrm{~Hz}, \mathrm{SiCH}_{2} \mathrm{CH}_{2}\right), 131.38(\mathrm{~s}$, $C$-aryl phosphine), 133.48 (m, $C$-aryl phosphine), 140.36 (s, $C$-aryl phosphine). ${ }^{19} \mathrm{~F}$ NMR $\left(\mathrm{CD}_{2} \mathrm{Cl}_{2}, 282.4 \mathrm{MHz}\right): \delta-124.61$ $\left(\mathrm{s}, 12 \mathrm{~F}, \mathrm{C} F_{2}\right),-121.62\left(\mathrm{~s}, 12 \mathrm{~F}, \mathrm{C} F_{2}\right),-121.34\left(\mathrm{~s}, 12 \mathrm{~F}, \mathrm{C} F_{2}\right)$ $-120.46\left(\mathrm{~s}, 12 \mathrm{~F}, \mathrm{CF}_{2}\right),-114.43\left(\mathrm{~s}, 12 \mathrm{~F}, \mathrm{CF}_{2}\right),-79.54(\mathrm{~s}, 18 \mathrm{~F}$, $\left.\mathrm{CF}_{3}\right) .{ }^{31} \mathrm{P}\left\{{ }^{1} \mathrm{H}\right\}$ NMR $\left(121.5 \mathrm{MHz}, \mathrm{CD}_{2} \mathrm{Cl}_{2}\right): \delta 28.50 \mathrm{MHz}(\mathrm{s})$. Due to instability of the complex, no satisfactory elemental analyses could be obtained.

Catalytic Studies. The following description for $[\operatorname{Pd}(0)$ $\left(\mathrm{PPh}_{3}\right)_{2}$ (MA)] is illustrative for all catalysis runs using the zerovalent $\mathrm{Pd}$ alkene complexes. In a Schlenk vessel was weighed the starting palladium complex $(27.0 \mathrm{mg}, 0.037$ mmol). A second Schlenk vessel was charged with styrene (580.7 $\mathrm{mg}, 5.58 \mathrm{mmol}, 151$ equiv with respect to $\mathrm{Pd}$ ), $p$ toluenesulfonic acid monohydrate $(209.7 \mathrm{mg}, 1.10 \mathrm{mmol}, 30$ equiv with respect to $\mathrm{Pd}), \mathrm{H}_{2} \mathrm{O}(0.38 \mathrm{~mL}, 600$ equiv with respect to $\mathrm{Pd}$ ), $n$-decane (22 $\mathrm{mg}, 0.15 \mathrm{mmol}), \mathrm{MeOH}(8.7 \mathrm{~mL})$, and $\alpha, \alpha^{\prime}, \alpha^{\prime \prime}$-trifluorotoluene $(8.7 \mathrm{~mL})$. The resulting clear solution was mixed and then transferred via syringe to the Schlenk vessel containing the palladium complex. This mixture was divided equally over the two autoclaves. After sealing they were evacuated three times and refilled with $\mathrm{N}_{2}$, followed by flushing three times with CO (15 bar). The autoclaves were heated to the desired temperature and subsequently pressurized with CO (30 bar), which was taken as the starting point. After the desired reaction time had passed, the autoclaves were cooled and carefully vented and their contents collected. Analysis was performed via GC using $n$-decane as an internal standard. The autoclaves were cleaned by washing with aqua regia, water, and acetone, respectively.

NMR Study on the Reaction of $\left[\operatorname{Pd}(0)\left(\mathrm{PPh}_{3}\right)_{2}\left(\mathrm{C}_{2} \mathrm{H}_{4}\right)\right]$ with 3 equiv of $p$-Toluenesulfonic Acid in $\mathrm{MeOH}-d_{4}$. In a Schlenk vessel the starting palladium complex (77.0 mg, 0.12 mmol) was weighed. To this was added a solution of $p$ toluenesulfonic acid $(66.9 \mathrm{mg}, 0.35 \mathrm{mmol}, 3$ equiv) in $\mathrm{MeOH}-$ $d_{4}(0.5 \mathrm{~mL})$. After about $1 \mathrm{~min}$, when the initial gray suspension had turned into a clear dark red solution, this solution was transferred via syringe to a $5 \mathrm{~mm}$ NMR tube. The NMR tube was placed in the NMR spectrometer and shimmed, and the ${ }^{1} \mathrm{H}(500 \mathrm{MHz}),{ }^{1} \mathrm{H}\left\{{ }^{31} \mathrm{P}\right\}$, and ${ }^{31} \mathrm{P}\left\{{ }^{1} \mathrm{H}\right\}$ NMR spectra were recorded. For the ${ }^{1} \mathrm{H}\left\{{ }^{31} \mathrm{P}\right\}$ NMR experiment, ${ }^{31} \mathrm{P}$ decoupling was performed using the GARP-1 sequence.

Supporting Information Available: CIF files of crystal structure data collection and refinement parameters, atomic coordinates, bond lengths and angles, and anisotropic displacement parameters for $\mathbf{6}$. This material is available free of charge via the Internet at http://pubs.acs.org.

\section{OM0506419}

(52) Spek, A. L. J. Appl. Crystallogr. 2003, 36, 7. 